SUBSTRATE TYPE AND PRETREATMENT TYPE EFFECTS ON VFA PRODUCTION

by

Gamsathvani Sivanantham

B. Eng., Ryerson University, 2017

\author{
An MRP \\ presented to Ryerson University \\ in partial fulfillment of the \\ requirements for the degree of \\ Master of Engineering \\ in the program of \\ Civil Engineering
}

Toronto, Ontario, Canada, 2019

(C) Gamsathvani Sivanantham, 2019 


\section{Author's Declaration}

I hereby declare that I am the sole author of this MRP. This is a true copy of the MRP including any required final revisions.

I authorize Ryerson University to lend this MRP to other institutions or individuals for the purpose of scholarly research.

I further authorize Ryerson University to reproduce this MRP by photocopying or by other means, in total or in part, at the request of other institutions or individuals for the purpose of scholarly research.

I understand that my MRP may be made electronically available to the public. 


\title{
Substrate Type and Pretreatment Type Effects on VFA Production
}

Civil Engineering, 2019

Gamsathvani Sivanantham

Master of Engineering, Ryerson University

\begin{abstract}
In the following report, the effects of substrate type and pretreatment type on the production of volatile fatty acids during anaerobic digestion was analyzed. First, the effects on volatile fatty acid production due to substrate type were investigated. It was determined that wastes that consisted of higher concentrations of carbohydrates would generate higher concentrations of volatile fatty acids during anerobic digestion. In the investigation it was evident that food waste had higher volatile fatty acid yields compared to sludge due to the carbohydrate content. Furthermore, the effects on volatile fatty acid production due to pretreatment type were also investigated. Thermal, chemical, physical and combined pretreatments were analysed. The various types of the different pretreatments and their effects on volatile fatty acid production during anaerobic digestion were discussed in depth.
\end{abstract}




\section{Acknowledgements}

I would initially like to thank my supervisor, Dr. Elsayed Elbeshbishy, for providing me with this opportunity to gain research experience and better my knowledge on the topic of volatile fatty acid production. Furthermore, I would like to express my gratitude to Dr. Elsayed Elbeshbishy for being available throughout the course of my Master of Engineering for assistance with my questions and concerns regarding the project.

Additionally, I would like to thank Ehssan Hosseini Koupaie for assisting us with the commencement of this project. I would like to express my gratitude to him for being available to assist me with commencing this project and addressing my questions and concerns.

Lastly, I would like to thank Dr. Hisham Hafez for instilling knowledge through his Bioenergy and Biofuels course in my last semester. This course provided me with further understanding of anaerobic digestion, which I was able to apply into the following MRP. 


\section{Table of Contents}

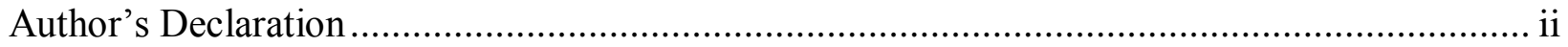

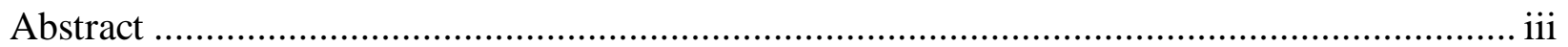

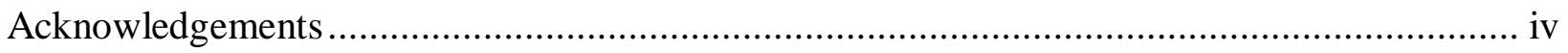

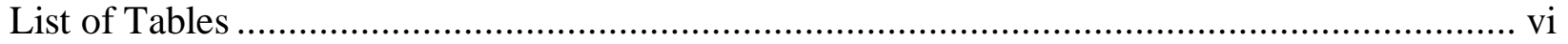

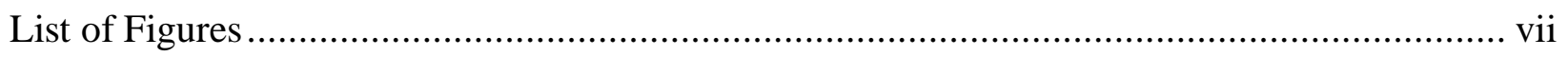

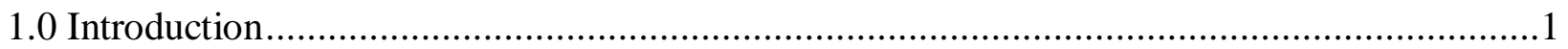

2.0 Substrate Type Effects on Volatile Fatty Acid Production ...................................................

2.1 Primary Sludge, Waste Activated Sludge and Combined Sludge........................................ 3

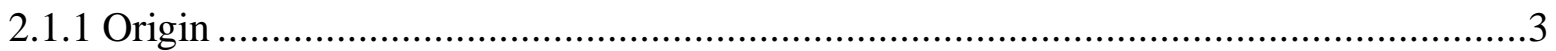

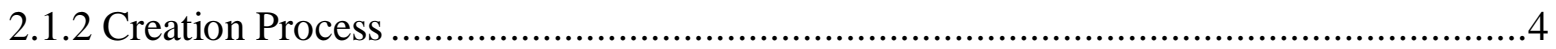

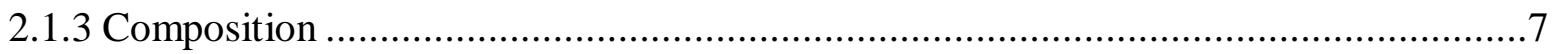

2.1.4 Effect of Sludge on Volatile Fatty Acid Production...................................................

2.2 Solid Waste: Food Waste and Yard Waste ………........................................................10

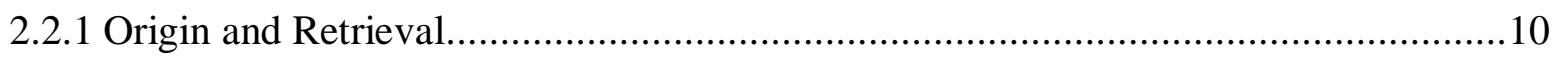

2.2.2 Effect of Solid Waste on Volatile Fatty Acids Production .........................................13

3.0 Types of Pretreatment and Effect on Volatile Fatty Acid Production ...................................18

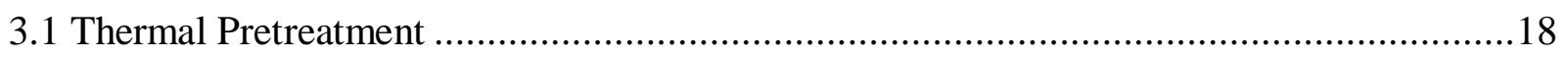

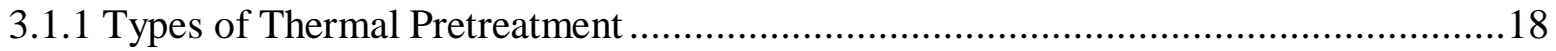

3.1.2 Effect of Thermal Pretreatment on Volatile Fatty Acids Production ..........................21

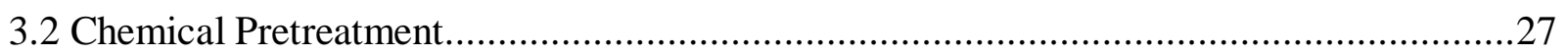

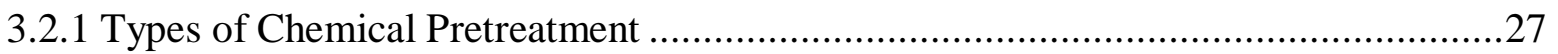

3.2.2 Effect of Chemical Pretreatment on Volatile Fatty Acids Production ........................29

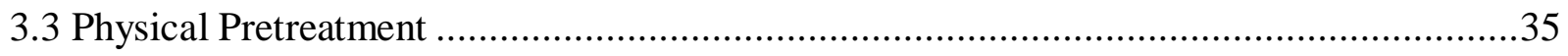

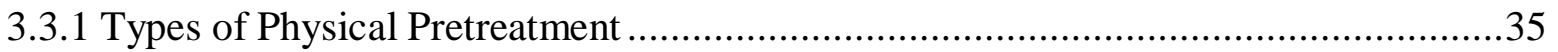

3.3.2 Effect of Physical Pretreatment on Volatile Fatty Acids Production ............................37

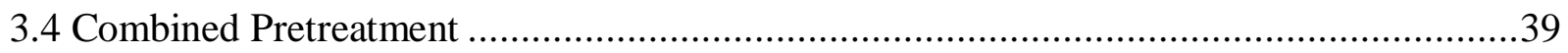

3.4.1 Effect of Combined Pretreatment on Volatile Fatty Acids Production ........................39

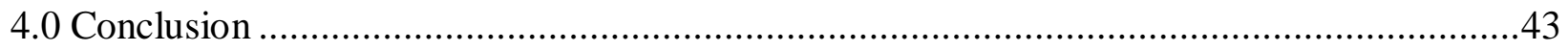

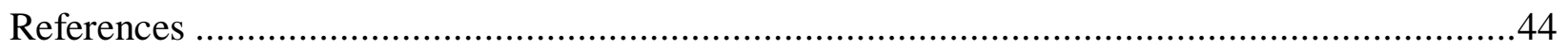




\section{List of Tables}

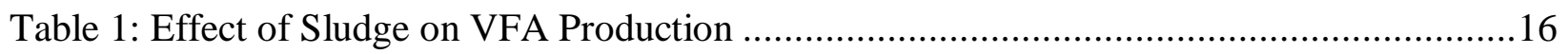

Table 2: Effect of Municipal Solid Waste on Volatile Fatty Acid Production............................17

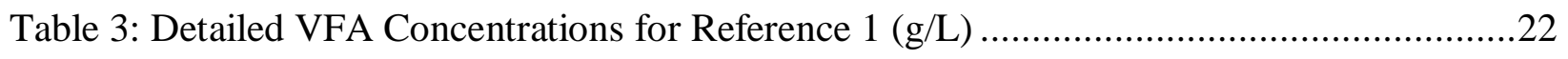

Table 4: Effects of Thermal Pretreatment on VFA Production ...........................................26

Table 5: Effects of Chemical Pretreatment on VFA Production ..............................................34

Table 6: Effects of Physical Pretreatment on VFA Production .................................................39

Table 7: Effects of Combined Pretreatment on VFA Production .............................................42 


\section{List of Figures}

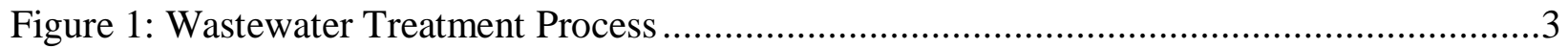

Figure 2: Primary Sedimentation Tank ............................................................................5

Figure 3: Waste Activated Sludge Process........................................................................ 7

Figure 4: Causes of Food Waste in USA …................................................................ 11

Figure 5: Characteristics of Food Waste, Aerobic Activated Sludge and Anaerobic Activated

Sludge for Ref 6 ............................................................................................. 13

Figure 6: Anaerobic Inoculum and Food Waste Effect on VFA .......................................... 14

Figure 7: Aerobic Inoculum and Food Waste Effect on VFA ............................................... 14

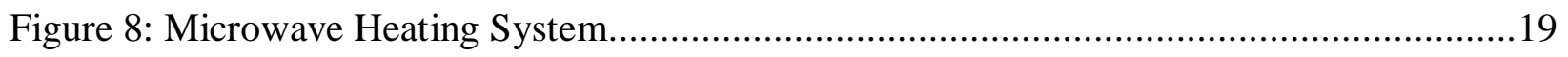

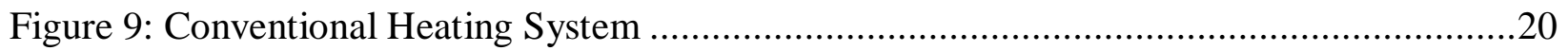

Figure 10: Cambi Process..............................................................................................20

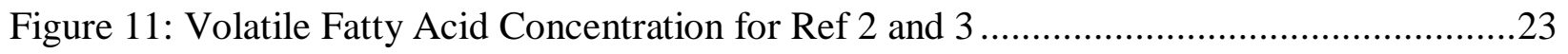

Figure 12: Effect of Chemical Pretreatment ......................................................................27

Figure 13: VFA Concentration after Ozone, Alkaline and Ozone with Alkaline Pretreatment ....30

Figure 14: Biomethane Production ................................................................................... 31

Figure 15: Solid Recovery After Acid Pretreatment...........................................................32

Figure 16: Solid Recovery After Alkaline Pretreatment .......................................................32

Figure 17: VFA Production After Alkaline Pretreatment .................................................33

Figure 18: VFA Production After Acid Pretreatment ......................................................33

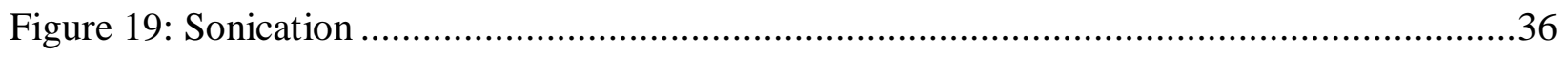

Figure 20: Sonication Mechanism Implementation in a Plant ...........................................36

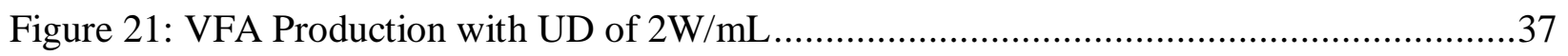

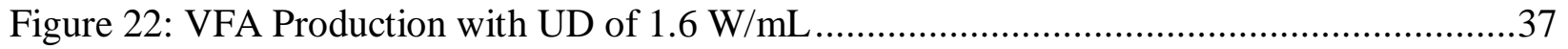

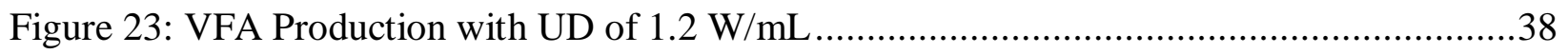




\subsection{Introduction}

Anaerobic digestion is the utilization of micro-organisms, like bacteria, to degrade organic and inorganic waste through natural processes (Hafez, 2019). The objective of anaerobic digestion is to destruct organic materials and pathogens (Hafez, 2019). Destructing organic material will result in more stable sludge to be released into the environment due to the reduction in oxygen demand in sludge (Hafez, 2019). This is accomplished through oxidation (Hafez, 2019). Destruction of pathogens is completed through anerobic digestion completed at $35^{\circ} \mathrm{C}$ for 15 days (Hafez, 2019). The anaerobic digestion process can be broken down into three stages. The first stage is hydrolysis and fermentation (Hafez, 2019). During this stage various facultative bacteria are introduced to the substrate to convert carbohydrates into simple sugars, proteins into amino acids, sugars and amino acids into fatty acids and alcohols and finally lipids into long chain fatty acids (Hafez, 2019). The second stage is acetogenesis and dehydrogenation (Hafez, 2019). During this stage various acid forming bacteria are utilized to convert ethanol and fatty acids, that were created during the hydrolysis and fermentation process, into acetic acid and hydrogen (Hafez, 2019). The third and final stage is methanogenesis (Hafez, 2019). During the final stage, the acetic acid, hydrogen and residual organic matter is converted into methane using methane forming bacteria (Hafez, 2019).

Volatile fatty acids are short chain acids (Wee Shen Lee, 2013). Volatile fatty acids can be used in the formation of other products, such as bioenergy, and in the process of removal of nutrients from wastewater (Wee Shen Lee, 2013). Glucose and sucrose are the main driving force in the production of volatile fatty acids (Wee Shen Lee, 2013). Therefore, wastes that have high concentrations of organics, such as sludge, food waste and yard waste consist of high 
concentrations of glucose and sucrose making them the ideal substrate types used in the production of volatile fatty acids (Wee Shen Lee, 2013). The polysaccharides, proteins and lipids in the waste undergo hydrolysis to be broken down into monosaccharaides, amino acids and long chain fatty acids (Wee Shen Lee, 2013). These monomers then undergo acidogenesis where they are broken down into volatile fatty acids, such as acetic acid, propionic acid and butyric acid (Wee Shen Lee, 2013).

Volatile fatty acid production depends on the conditions of anaerobic digestion. As discussed, the substrate type being utilized in anaerobic digestion can affect the production of volatile fatty acids. The effects of utilizing wastes such as primary sludge, waste activated sludge, combined sludge, food waste and yard waste will be further discussed in the report. Furthermore, pretreatment, which is completed on the substrate before anaerobic digestion, also has an affect on the production of anaerobic digestions. These pretreatments include thermal pretreatment, chemical pretreatment, physical pretreatment and combined pretreatment. These pretreatments and its effects on volatile fatty acid production will be further discussed in the report as well. 


\subsection{Substrate Type Effects on Volatile Fatty Acid Production}

\subsection{Primary Sludge, Waste Activated Sludge and Combined Sludge}

\subsubsection{Origin}

Primary sludge is a product of wastewater treatment. Wastewater treatment involves biological processes that mimic the natural processes found in a body of water that experiences a discharge of wastewater (Lenntech, 2019). Technology is used to recreate the natural process of organic matter being converted into inert material that is then disposed of (Lenntech, 2019). The introduction of technology emphasizes the importance of operational conditions for higher productivity (Lenntech, 2019).

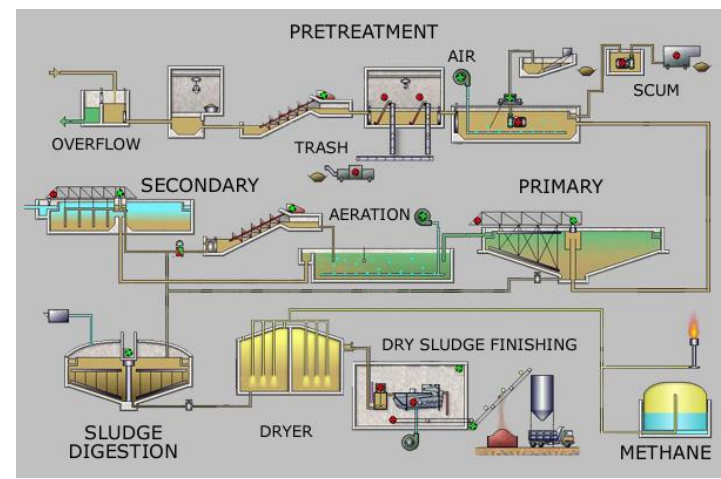

Figure 1: Wastewater Treatment Process

Waste activated sludge is the quantity of sludge made of organisms that form in the aeration tank (NESC, 2003). Sludge particles interact with bacteria, fungi and protozoa, hence it being called activated (NESC, 2003). The difference between waste activated sludge and primary sludge is that waste activated sludge contains various living organisms (NESC, 2003). Waste activated sludge is the product of the waste activated sludge process (NESC, 2003). The objectives of activated sludge process are to oxidize carbonaceous matter, such as biological matter, and nitrogenous matter, remove phosphate, dispel entrained gases, such as carbon 
dioxide, ammonia and nitrogen, and produce a floc of biological matter that can settle with ease and a liquor contained a low quantity of dissolved and suspended solids (NESC, 2003). The process utilizes aerobic microorganisms for consuming organic matter found in influent (NESC, 2003). During this process, the microorganisms will flocculate, which makes it easier for it to settle and be removed and allow for the liquor to be free of suspended solids and organic matter (NESC, 2003).

\subsubsection{Creation Process}

Wastewater treatment is comprised of various stages. Primary sludge is the product of the second stage called Primary Treatment (Britannica, 2019). The first stage is pretreatment. During pretreatment, the larger and easily removable solids are separated from the influent (Britannica, 2019). The removal of these solids is done using bar screens, which is a mechanism consisting of a screen that rakes the influent to collect the larger solids (Britannica, 2019). The kinetics of the bar screen depends on the accumulation of solids as well as the flow rate (Britannica, 2019). This prevents the reactor from being clogged or damaged through the treatment process (Britannica, 2019). Examples of solids removed during the pretreatment stage are garbage, and tree limbs and branches (Britannica, 2019). During this stage, grit is also removed from the influent (Britannica, 2019). Grit is comprised of sand, gravel and organic matter, such as eggshells and seeds (Britannica, 2019). This process takes place in a grit chamber where the influent velocity is altered to allow for the settling of grit (Britannica, 2019). The reason for this stage is to ensure there is no accumulation of large amounts of grits in the aeration tanks, aerobic digesters, pipelines, channels and conduits (Britannica, 2019). This will allow for minimal damages to the reactor and minimal maintenance of the reactor (Britannica, 2019). Flow equalization also occurs during this stage (Britannica, 2019). Equalization basins are used to hold the influent to ensure a steady flow into the reactor (Britannica, 2019). It is best utilized during peak-wet weather, when 
dilution is required because there is waste with high concentrations of toxicity or when maintenance needs to be completed to the reactor (Britannica, 2019). An equalized flow will also ensure the productivity of the remaining equipment (Britannica, 2019). Furthermore, in the pretreatment stage, fat and grease removal is also conducted (Britannica, 2019). This is accomplished by running the effluent through a small tank with skimmers (Britannica, 2019). The skimmers collect majority of the floating fats and grease (Britannica, 2019). This can also be done in the primary treatment stage (Britannica, 2019). All in all, after the influent has passed through the pretreatment stage, it consists of little to no large solids, grit and fats and oils (Britannica, 2019). The next stage, as mentioned before, is the primary treatment stage. Primary sludge is the product of this stage (Britannica, 2019). The goal of primary treatments is to allow for organic and inorganic solids to settle for disposal (Britannica, 2019). During primary treatment, the influent flows into primary clarifiers, also know as primary sedimentation tanks (Britannica, 2019). In the primary clarifiers, sludge settles to the bottom of the tank and fats and oils float to the top (Britannica, 2019). This is where the skimmers can also be applied to mechanically remove the fats and oils (Britannica, 2019). The sludge at the bottom is collected. This sludge is primary sludge and can be pumped to a sludge treatment facility (Britannica, 2019).

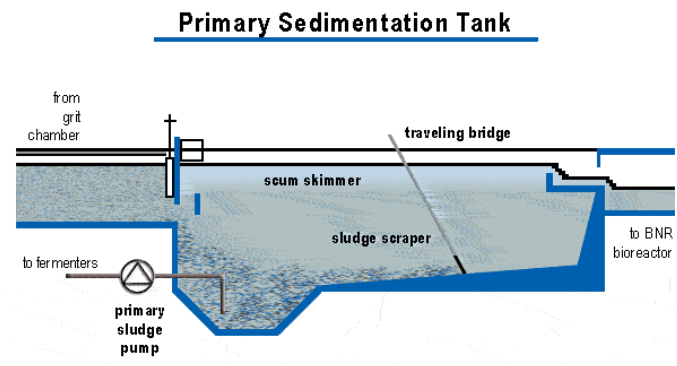

Figure 2: Primary Sedimentation Tank 
Typically, the activated sludge process consists of three components (The International Water Association Publishing, 2019). These are the aeration tank, secondary clarifier, also known as the settling tank, and return activated sludge equipment (The International Water Association Publishing, 2019). Firstly, the influent flows into the aeration tank. In the aeration tank aerobic biological microorganisms, such as bacteria, consume the organic material found in the influent (The International Water Association Publishing, 2019). Air or oxygen is also introduced into the aeration tank because these microorganisms are aerobic and require oxygen to exist (The International Water Association Publishing, 2019). These microorganisms can multiply and flocculate as they are provided enough organic material to consume and oxygen (The International Water Association Publishing, 2019). The retention time averages between $4-$ 8 hours and this is how long it approximately takes for the microorganisms to consume all the available organic material found in the sludge (The International Water Association Publishing, 2019). The mixture of raw sewage, or influent, and flocculated microorganisms is called mixed liquor suspended solids (The International Water Association Publishing, 2019). The mixed liquor suspended solids flow into the secondary clarifier where settling occurs (The International Water Association Publishing, 2019). The flocculated microorganisms settle to the bottom of the clarifier (The International Water Association Publishing, 2019). This sludge is routed back to the aeration tank as return activated sludge through equipment (The International Water Association Publishing, 2019). The excess sludge that is not routed back as returned activated sludge, to ensure balance of food to biomass ratio in the biological processes of the aeration tank, is sent out for further treatment (The International Water Association Publishing, 2019). This excess sludge that is not further utilized in the activated sludge process is called waste activated sludge (The International Water Association Publishing, 2019). 


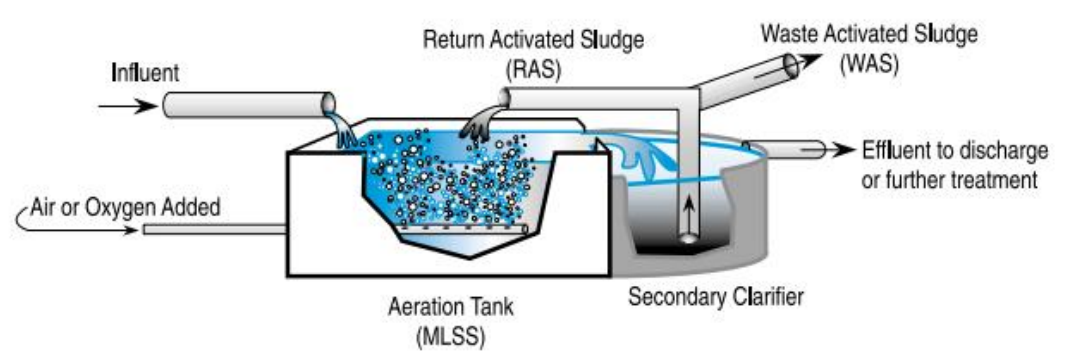

Figure 3: Waste Activated Sludge Process

\subsubsection{Composition}

The composition of primary sludge depends on the location of the catchment area (Britannica, 2019). Catchment areas can consist of various areas, such as residential, commercial or industrial areas (Britannica, 2019). These different kinds of areas produce different kinds of wastes, which ultimately change the composition of the sludge being fed through the reactor (Britannica, 2019). Generally, primary sludge consists of large amounts of organic matter, feces, paper and textiles (Britannica, 2019). During primary pretreatment, it is estimated that $25-50 \%$ of biochemical oxygen demand, $50-75 \%$ total suspended solids and $65 \%$ of oil and grease is removed (Britannica, 2019). Furthermore, during primary treatment, organic nitrogen and phosphorus and heavy metals are removed (Britannica, 2019). Dissolved and colloidal material in influent is not removed during primary treatment (Britannica, 2019).

Waste activated sludge is comprised of various kinds of microorganisms (NESC, 2003). Of the microorganisms, $95 \%$ are bacteria and the other $5 \%$ is higher organisms, such as protozoa (NESC, 2003). Bacteria are found in a group comprised of unicellular microorganisms (NESC, 2003). Their cells have cell walls but do not have organelles and a set nucleus (NESC, 2003). Bacteria do not require sunlight for reproduction, which makes it beneficial in the activated sludge process (NESC, 2003). It plays a large role in the stabilization of organic matter by consuming the organic matter found in influent sludge (NESC, 2003). Examples of bacteria 
found in waste activated sludge are spirillum, viteroscilla, sphaerotilius, beggiotoa, and zoogloea (NESC, 2003). Protozoa are single celled eukaryotes (NESC, 2003). They either live freely or are parasites (NESC, 2003). They also, like bacteria, ingest organic matter (NESC, 2003). Therefore, they assist with the consumption of organic material in the aeration tank of the activated sludge process and reproduce and flocculate along with bacteria (NESC, 2003). Examples of protozoa are paramecium, nematode, rotifers and ciliate (NESC, 2003). The microorganisms that are dominantly found in waste activated sludge are aerobic bacteria (NESC, 2003). Concentration of the various microorganisms can depend on the retention time in the aeration tank (NESC, 2003). For example, larger concentrations of rotifers, an example of protozoa, can be achieved with a longer retention time in the aeration tank (NESC, 2003). Furthermore, concentration of the microorganisms can depend on the food to mass ratio (NESC, 2003). For example, free-swimming ciliates, an example of protozoa, have a higher concentration as the food to mass ration decreases whereas stationary ciliates when the food to mass ratio is higher provide a lower concentration (NESC, 2003). Higher concentrations of certain microorganisms can indicate the quality of the sludge (NESC, 2003). Bacteria such as flagellates and filamentous at high concentrations indicate poor quality sludge (NESC, 2003). Therefore, when running the activated sludge process, technicians can control the operation of the reactor to ensure desired reproduction of the various microorganisms and high-quality waste activated sludge (NESC, 2003).

\subsubsection{Effect of Sludge on Volatile Fatty Acid Production}

The effect on volatile fatty acid production due to the utilization of sludge as substrate type can be outlined in Table 1. Reference 3 from Table 1 represents anaerobic digestion completed on primary sludge and industrial wastewater. The primary sludge collected for this study was collected from the Water Pollution Control Centre (I. Maharaj, 2001). The industrial 
wastewater was collected from the settling tanks at Old Dutch Food Company (I. Maharaj, 2001). They were stored at $6^{\circ} \mathrm{C}$ in plastic containers where the volatile fatty acid concentrations only varied by $8 \%$ at the end of storage (I. Maharaj, 2001). These two influents were fed into two separate continuous-flow completely mix anaerobic reactors (I. Maharaj, 2001). The first component that was analyzed was hydraulic retention time (I. Maharaj, 2001). It was determined that the maximum volatile fatty acid concentrations for both reactors were achieved at a hydraulic retention time of 30 hours (I. Maharaj, 2001). The volatile fatty acid concentrations then decreased when hydraulic retention times were at 48 hours and 60 hours (I. Maharaj, 2001). This decrease in volatile fatty acids can be due to the decrease in volatile suspended solid concentrations in the reactors (I. Maharaj, 2001). When comparing the volatile fatty acid analysis for both the reactor consisting of municipal primary sludge and the reactor consisting of municipal and industrial wastewater, it was determined that the combined municipal and industrial wastewater had yielded higher for volatile fatty acid production (I. Maharaj, 2001). This is due to the excess starch found in the wastewater from the Old Dutch Food Company (I. Maharaj, 2001). The second component that was analyzed was the temperatures affect on volatile fatty acid production (I. Maharaj, 2001). It was determined that volatile fatty acid concentrations were highest at $25^{\circ} \mathrm{C}$ but as temperature decreased so did the volatile fatty acid concentrations (I. Maharaj, 2001). This is because lower temperatures have and effect on acidogenic bacteria (I. Maharaj, 2001). It was also determined that the municipal and industrial wastewater had higher yields of volatile fatty acids due to the excess starch (I. Maharaj, 2001). Further investigation was completed to determine the composition of the volatile fatty acid (I. Maharaj, 2001). In the reactor that had the mixed industrial and municipal wastewater consisted of 56-74\% acetic acid, 10-18\% propionic acid, and 9-19\% n-butyric acid (I. Maharaj, 2001). In 
the reactor that consisted of only primary sludge consisted of $61-67 \%$ acetic acid, $24-35 \%$ propionic acid, 1-4\% n-butyric acid (I. Maharaj, 2001). The reason why n-butyric is higher in the reactor that consisted of both municipal and industrial wastewater is due to the higher concentration of carbohydrates (I. Maharaj, 2001). All in all, the municipal industrial wastewater consisted of higher concentrations of carbohydrates that resulted in higher concentrations of volatile fatty acids when adjusting conditions, such as hydraulic retention time and temperature.

\subsection{Solid Waste: Food Waste and Yard Waste}

\subsubsection{Origin and Retrieval}

The definition of food waste can differ from country to country. Food waste, as defined by the United States Environmental Protection Agency, is residual food that has either not been eaten or used in the preparation process (Wikipedia, 2019). The sources of food waste can be from residential locations and commercial locations, which can be restaurants and grocery stores (Wikipedia, 2019). Food waste is the second largest type of municipal solid waste produced, making up $18 \%$ of waste stream produced. Instead of sending the food waste to landfills for disposal, it can be used to generate other products, such as compost and energy (Wikipedia, 2019).

There are four main causes for the creation of food waste. The first cause is production. Crops can be discarded in the process of planting and harvesting (Wikipedia, 2019). During these stages, crops can experience unexpected conditions, such as pest infestation, severe weather or lack of necessities, like temperature and precipitation (Wikipedia, 2019). There are also regulations and standards that need to be met for crops to be distributed (Wikipedia, 2019). Crops that do not meet these standards and regulations are discarded as food waste (Wikipedia, 2019). The second cause is food processing. During the post harvest stages, storage and handling 
of the crops can lead to crops degradation due to outside conditions (Wikipedia, 2019). This degradation can cause loss in edibility of the crop as well as cause the crops to not meet the regulations and standards made for the distribution of the crops (Wikipedia, 2019). These crops are discarded as food waste (Wikipedia, 2019). The third cause is retail. Products are given an expiration date, best before date or sell by date, which is decided by the retailer to ensure quality products. These dates are determined using standards and policies that retailers have created (Wikipedia, 2019). To ensure the products being sold to consumers meet these standards many products are discarded even if the products are still edible (Wikipedia, 2019). Products are also discarded as food waste if they do not meet appearance standards, as customers will most likely avoid these products (Wikipedia, 2019). The last cause is consumption. Food waste is generated when consumers choose to discard of products when the assumed best before and expiration dates was reached (Wikipedia, 2019). Consumers also discard products during preparation and consumption (Wikipedia, 2019). Depending on the habits of the consumer, they may choose to waste products (Wikipedia, 2019). They may not use the entire product when preparing different meals and choose to discard the product (Wikipedia, 2019). They may not complete the meal they have prepared and choose to discard the residue product as food waste (Wikipedia, 2019).

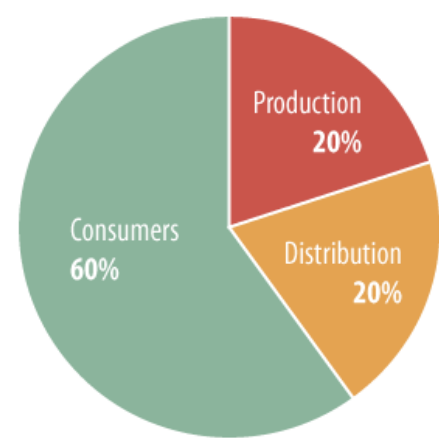

Figure 4: Causes of Food Waste in USA 
Once producers, retailers and consumers have decided to discard of food crops, the food waste is collected (Wikipedia, 2019). Depending on the location, food waste can be collected with general waste or separately through a collection system (Wikipedia, 2019). Countries are taken initiative to separate organics from other waste by introducing programs such as the green bin (compost) bins. Wastes are collected regularly and then disposed (Wikipedia, 2019). There are various disposal options for food waste, such as landfill, animal feed, composting, and anaerobic digestion (Wikipedia, 2019).

Yard waste can be referred to as vegetative waste (Encyclopedia.com, 2019). Yard waste does not include food and animal waste (Encyclopedia.com, 2019). Examples of yard waste are leaves, grass clipping, tree trimming and other residue from plants (Encyclopedia.com, 2019). The typical source of yard waste is residential areas (Encyclopedia.com, 2019). They come from maintaining the greenery at a home (Encyclopedia.com, 2019). They make up to 7\% of waste stream produced (Encyclopedia.com, 2019). This combined with food waste makes up to $25 \%$ of waste stream that can be used for other reasons (Encyclopedia.com, 2019).

The collection of yard waste occurs regularly (Encyclopedia.com, 2019). Most communities have established a program for yard waste, such as the use of a bin labeled yard waste or the use of brown bags (Encyclopedia.com, 2019). These programs take the initiative to properly dispose of yard waste instead of sending it to landfills along with general waste to biodegrade (Encyclopedia.com, 2019). It is collected through a collection system established by the government (Encyclopedia.com, 2019). Instead of disposal, yard waste can be used to create topsoil, can be mixed with sewage and processed to create compost, and can be sent to facilities to be converted into renewable energy (Encyclopedia.com, 2019). 


\subsubsection{Effect of Solid Waste on Volatile Fatty Acids Production}

The effect of municipal solid waste, including food waste and yard waste, being used as substrate during anaerobic digestion on volatile fatty acid production is outlined in Table 2 . Reference 4 outlines anaerobic digestion completed on food waste and its affect on volatile fatty acid production through representation of concentration of volatile fatty acids and volatile fatty acid yields (Kun Wang, 2014). The food waste utilized for this experiment was collected from the canteen on a university (Kun Wang, 2014). It consisted of rice, vegetables and meat. Solid materials such as bones were sorted out and the residual was grinded to create slurry and later sieved (Kun Wang, 2014). The inoculums utilized in this experiment are anaerobic activated sludge, which was attained from an up-flow anaerobic sludge bed (Kun Wang, 2014). Another inoculum that was used was aerobic activated sludge, which was attained from the secondary settling tank of a wastewater treatment plant (Kun Wang, 2014). Before inoculation of the inoculum and the food waste, the sludge, also known as the inoculum was rinsed under tap water for the removal of organic matter (Kun Wang, 2014). Characteristics of the food waste and the two inoculums can be found in Figure 5.

\begin{tabular}{lcll}
\hline Parameter & Food waste & Inoculum AE & Inoculum AN \\
\hline pH & 6.1 & 6.9 & 6.8 \\
TS $(\%)$ & 24.0 & 6.3 & 12.0 \\
VSS/TSS (\%) & 96.2 & 72 & 70 \\
SCOD $(\mathrm{g} / \mathrm{L})$ & 25.2 & - & - \\
Total carbohydrate $(\%)$ & 39.5 & 2.2 & 1.2 \\
Total nitrogen $(\%)$ & 1.8 & - & - \\
Total protein $(\%)$ & 11.0 & - & - \\
\hline
\end{tabular}

Figure 5: Characteristics of Food Waste, Aerobic Activated Sludge and Anaerobic Activated Sludge for Ref 6 Organic matter is a driving force in volatile fatty acid production. Food waste is made up of polysaccharides that degrades to glucose (Kun Wang, 2014). The glucose then degrades further 
into pyruvate, which can be used to create volatile fatty acids, such as acetate and butyrate using enzymatic processes (Kun Wang, 2014). Carbohydrates are rapidly consumed during fermentation, which can explain the high production of volatile fatty acids (Kun Wang, 2014). The $\mathrm{pH}$ of the fermentation process can affect the food wastes ability to convert into volatile fatty acids. In this experiment, the $\mathrm{pH}$ that resulted in higher concentrations of volatile fatty acids was pH 5 and 6 (Kun Wang, 2014). The inoculum used for inoculation did not affect this (Kun Wang, 2014). As presented in the last row, the food waste that was inoculated with anaerobic activated sludge at $\mathrm{pH}$ resulted in the highest yield of volatile fatty acids of $918.23 \mathrm{mg} / \mathrm{g} \mathrm{VSS}$ (Kun Wang, 2014). The volatile fatty acid production over the span of days spent in a reactor can be represented in Figures 6 and 7.

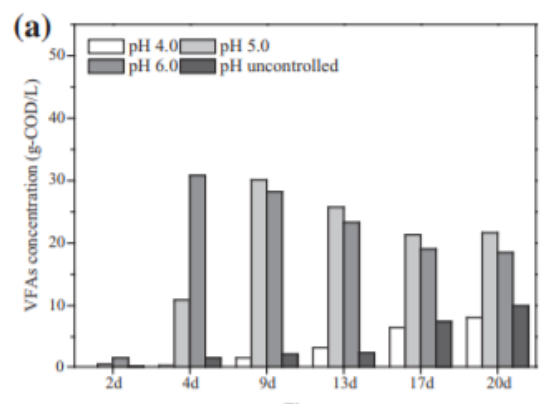

Figure 6: Aerobic Inoculum and Food Waste Effect on VFA

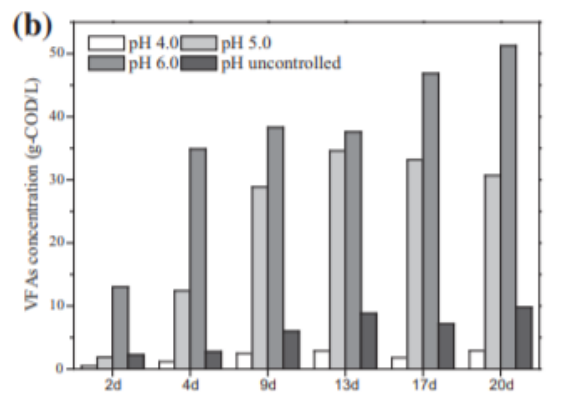

Figure 7: Anaerobic Inoculum and Food Waste Effect on VFA

As seen in Figures 6, aerobic inoculum and food waste at $\mathrm{pH} 4$ and uncontrolled $\mathrm{pH}$ resulted in an increase in volatile fatty acid production as time increased (Kun Wang, 2014). These concentrations of volatile fatty acids are still seen as smaller quantities compared to the concentrations found at other $\mathrm{pH}$. The maximum volatile fatty acid concentrations under different $\mathrm{pH}$ and inoculum conditions are also outlined in Table 2. All in all, with the findings it was determined that maximum volatile fatty acid concentrations were obtained when inoculation anaerobic activated sludge during fermentation of food waste (Kun Wang, 2014). Analyzing the table and Figure 6 and 7 emphasizes anaerobic inoculum's ability to produce higher 
concentrations of volatile fatty acids compared to aerobic inoculum (Kun Wang, 2014). This is due to anaerobic sludge having a higher quantity of bacteria for acidogenesis and microbial communities during anaerobic conditions (Kun Wang, 2014). Furthermore, the highest yield of volatile fatty acid found at $\mathrm{pH} 6$ with the use of anaerobic inoculum can be the result of a larger quantity of bacteria in hydrolysis and acidogenesis phases of anaerobic digestion compared to aerobic inoculum (Kun Wang, 2014). Also, food wastes consist of high quantity of carbohydrates, which can cause of excess production of volatile fatty acids (Kun Wang, 2014). Food waste's organic matter is composed largely of carbohydrates compared to protein, which explains the high production of volatile fatty acids. When using inoculum aerobic activated sludge, the composition of volatile fatty acids consisted mostly of acetic and butyric acids in $\mathrm{pH}$ conditions of 5 and 6 (Kun Wang, 2014). When using inoculum aerobic activated sludge, the composition of volatile fatty acids consisted mostly of acetic and propionic acids in $\mathrm{pH}$ conditions of 4 and uncontrolled (Kun Wang, 2014). When using inoculum anaerobic activated sludge, the composition of volatile fatty acids consisted mostly of butyric acids at $\mathrm{pH}$ levels of 5 and 6 (Kun Wang, 2014). Furthermore, the sample of food waste used for this investigation consisted mostly of carbohydrates. These carbohydrates, after completing fermentation, can result in a large quantity of volatile fatty acid production, such as the production of acetic and butyric acids (Kun Wang, 2014). In anaerobic conditions, acetic acids are most likely to be generated whereas in aerobic conditions propionic acids are more likely to be generated (Kun Wang, 2014). All in all, food wastes consist mainly of carbohydrates, which can be degraded through the process anaerobic digestion, or more specifically fermentation, to create volatile fatty acids in large quantities, depending on the conditions such as $\mathrm{pH}$ and inoculum utilized for inoculation. 
Table 1: Effect of Sludge on VFA Production

\begin{tabular}{|c|c|c|c|c|c|c|c|}
\hline Ref \# & $\begin{array}{l}\text { Type of } \\
\text { Sludge }\end{array}$ & $\begin{array}{c}\text { Organic } \\
\text { Content } \\
(\mathrm{mg} \mathrm{COD} / \mathrm{L}) \\
\end{array}$ & pH & Time & $\begin{array}{c}\text { VFA } \\
\text { Concentration }\end{array}$ & VFA Yield & Reference \\
\hline 1 & $\begin{array}{l}\text { Primary } \\
\text { Sludge }\end{array}$ & 22838 & - & 6 days & - & $85 \mathrm{mg}$ COD/g VSS & $\begin{array}{c}\text { Z Ji et al } \\
(2010)\end{array}$ \\
\hline 2 & $\begin{array}{l}\text { Primary } \\
\text { Sludge }\end{array}$ & 60631 & 10 & 5 days & - & $\begin{array}{c}60 \mathrm{mg} \mathrm{COD} / \mathrm{g} \\
\mathrm{VSS} / \mathrm{d}\end{array}$ & $\begin{array}{c}\text { H Wu et al } \\
(2009)\end{array}$ \\
\hline 3 & $\begin{array}{l}\text { Primary } \\
\text { Sludge }\end{array}$ & 343 & - & 10 days & - & $31 \mathrm{mg} / \mathrm{g} \mathrm{VSS} / \mathrm{d}$ & $\begin{array}{c}\text { I Maharaj et al } \\
(2001)\end{array}$ \\
\hline 4 & $\begin{array}{c}\text { Waste } \\
\text { Activated } \\
\text { Sludge }\end{array}$ & 5470 & 11 & 7 days & $2561 \mathrm{mg} \mathrm{TOC} / \mathrm{L}$ & - & $\begin{array}{c}\text { C Mengmeng } \\
\text { et at } \\
(2009)\end{array}$ \\
\hline 5 & $\begin{array}{c}\text { Waste } \\
\text { Activated } \\
\text { Sludge }\end{array}$ & 18657 & 9 & 5 days & - & $\begin{array}{c}298 \mathrm{mg} \mathrm{COD} / \mathrm{g} \\
\text { VSS }\end{array}$ & $\begin{array}{c}\text { P Zhang et al } \\
(2009)\end{array}$ \\
\hline 6 & $\begin{array}{c}\text { Waste } \\
\text { Activated } \\
\text { Sludge }\end{array}$ & 18657 & 8 & 9 days & - & $\begin{array}{c}368 \mathrm{mg} \mathrm{COD} / \mathrm{g} \\
\text { VSS }\end{array}$ & $\begin{array}{c}\text { P Zhang et al } \\
(2009)\end{array}$ \\
\hline 7 & $\begin{array}{c}\text { Waste } \\
\text { Activated } \\
\text { Sludge } \\
\end{array}$ & 14878 & - & 6 days & $339 \mathrm{mg}$ COD/L & - & $\begin{array}{c}\text { C Eskicioglu et } \\
\text { al (2008) }\end{array}$ \\
\hline 8 & $\begin{array}{c}\text { Waste } \\
\text { Activated } \\
\text { Sludge }\end{array}$ & 14890 & - & 6 days & $191 \mathrm{mg} \mathrm{COD} / \mathrm{L}$ & - & $\begin{array}{c}\text { S Jiang et al } \\
(2007)\end{array}$ \\
\hline 9 & $\begin{array}{c}\text { Combined } \\
\text { Sludge } \\
\end{array}$ & - & - & - & $11.10 \mathrm{~g} / \mathrm{L}$ & - & $\begin{array}{c}\text { W.S Lee et al } \\
(2013)\end{array}$ \\
\hline
\end{tabular}


Table 2: Effect of Municipal Solid Waste on Volatile Fatty Acid Production

\begin{tabular}{|c|c|c|c|c|c|c|c|}
\hline Ref \# & $\begin{array}{l}\text { Type of } \\
\text { Sludge }\end{array}$ & Seeding & $\mathbf{p H}$ & Time & VFA Concentration & VFA Yield & Reference \\
\hline 1 & Yard Waste & - & - & - & @ 30 days - 4000 ppm & - & $\begin{array}{c}\text { L Yu et al } \\
(2018)\end{array}$ \\
\hline 2 & Yard Waste & - & - & - & @ 30 days -4500 ppm & - & $\begin{array}{c}\text { L Yu et al } \\
(2018)\end{array}$ \\
\hline 3 & Yard Waste & - & - & - & @ 30 days -4500 ppm & - & $\begin{array}{c}\text { L Yu et al } \\
(2018)\end{array}$ \\
\hline \multirow[t]{8}{*}{4} & Food Waste & $\begin{array}{c}\text { Aerobic } \\
\text { Activated Sludge }\end{array}$ & 4 & 20 days & $8.07 \mathrm{~g} / \mathrm{L}$ & $\begin{array}{c}206.45 \mathrm{mg} / \mathrm{g} \\
\mathrm{VSS}_{\text {removal }}\end{array}$ & $\begin{array}{c}\text { K Wang et al } \\
(2014)\end{array}$ \\
\hline & Food Waste & $\begin{array}{c}\text { Aerobic } \\
\text { Activated Sludge }\end{array}$ & 5 & 9 days & $30.1 \mathrm{~g} / \mathrm{L}$ & $\begin{array}{c}445.17 \mathrm{mg} / \mathrm{g} \\
\mathrm{VSS}_{\text {removal }} \\
\end{array}$ & $\begin{array}{c}\text { K Wang et al } \\
(2014)\end{array}$ \\
\hline & Food Waste & $\begin{array}{c}\text { Aerobic } \\
\text { Activated Sludge }\end{array}$ & 6 & 4 days & $30.8 \mathrm{~g} / \mathrm{L}$ & $\begin{array}{c}481.85 \mathrm{mg} / \mathrm{g} \\
\mathrm{VSS}_{\text {removal }}\end{array}$ & $\begin{array}{c}\text { K Wang et al } \\
(2014)\end{array}$ \\
\hline & Food Waste & $\begin{array}{c}\text { Aerobic } \\
\text { Activated Sludge }\end{array}$ & $\mathrm{UC}$ & 20 days & $9.96 \mathrm{~g} / \mathrm{L}$ & $\begin{array}{c}229.06 \mathrm{mg} / \mathrm{g} \\
\mathrm{VSS}_{\text {removal }}\end{array}$ & $\begin{array}{c}\text { K Wang et al } \\
(2014)\end{array}$ \\
\hline & Food Waste & $\begin{array}{c}\text { Anaerobic } \\
\text { Activated Sludge }\end{array}$ & 4 & 20 days & $2.91 \mathrm{~g} / \mathrm{L}$ & $\begin{array}{c}124.30 \mathrm{mg} / \mathrm{g} \\
\mathrm{VSS}_{\text {removal }}\end{array}$ & $\begin{array}{c}\text { K Wang et al } \\
(2014)\end{array}$ \\
\hline & Food Waste & $\begin{array}{c}\text { Anaerobic } \\
\text { Activated Sludge }\end{array}$ & 5 & 13 days & $34.6 \mathrm{~g} / \mathrm{L}$ & $\begin{array}{c}650.6 \mathrm{mg} / \mathrm{g} \\
\mathrm{VSS}_{\text {removal }}\end{array}$ & $\begin{array}{c}\text { K Wang et al } \\
(2014)\end{array}$ \\
\hline & Food Waste & $\begin{array}{c}\text { Anaerobic } \\
\text { Activated Sludge }\end{array}$ & 6 & 20 days & $51.3 \mathrm{~g} / \mathrm{L}$ & $\begin{array}{c}918.23 \mathrm{mg} / \mathrm{g} \\
\mathrm{VSS}_{\text {removal }} \\
\end{array}$ & $\begin{array}{c}\text { K Wang et al } \\
(2014)\end{array}$ \\
\hline & Food Waste & $\begin{array}{c}\text { Anaerobic } \\
\text { Activated Sludge }\end{array}$ & $\mathrm{UC}$ & 20 days & $8.80 \mathrm{~g} / \mathrm{L}$ & $\begin{array}{c}337.51 \mathrm{mg} / \mathrm{g} \\
\mathrm{VSS}_{\text {removal }}\end{array}$ & $\begin{array}{c}\mathrm{K} \text { Wang et al } \\
(2014)\end{array}$ \\
\hline
\end{tabular}

*UC - Uncontrolled 


\subsection{Types of Pretreatment and Effect on Volatile Fatty Acid Production}

\subsection{Thermal Pretreatment}

Thermal treatment is the most studied and implemented form of pretreatment used in industrial settings for anaerobic digestion (Javkhlan Ariunbaatar, 2014). It allows for the removal of pathogens, the reduction in the viscosity of the digestate produced and allows for an enhanced dewatering process (Javkhlan Ariunbaatar, 2014). General outcomes of thermal pretreatment of organic materials are solubilization due to the destruction of the cell membranes, which in turn also affects the solubilization of COD and temperature (Javkhlan Ariunbaatar, 2014). A comparison of different thermal pretreatments concluded that there is not much difference between steam and electric heating, but microwave heating resulted in greater solubilization of biopolymers (Javkhlan Ariunbaatar, 2014). To further explain, microwave heating allowed for hemicellulose and lignin, both components of lignocellulose, to be solubilized. Furthermore, thermal pretreatment at temperatures higher that $170^{\circ} \mathrm{C}$ or longer retention times result in chemical reactions to occur and bonds to be created, such as Mallaird reaction (Javkhlan Ariunbaatar, 2014). Mallaird reaction between carbohydrates and amino acids result in the creation of substrate that is more difficult to biodegrade (Javkhlan Ariunbaatar, 2014). Also, depending on the substrate type and the temperature of pretreatment, thermal pretreatment can cause volatile organics reduction and/or the creation of biomethane (Javkhlan Ariunbaatar, 2014). There are various types of thermal pretreatment that can be conducted on substrates, which include microwave heating, conventional heating and Cambi.

\subsubsection{Types of Thermal Pretreatment}

Microwave heating and conventional heating are different. Microwave heating involves the heating of just the material. A wet sample is placed in the vessel where the temperature is 
increased. Electromagnetism, the process of energy being absorbed by water, fat and sugar molecules of the wet sample, takes place during microwaving. When applying microwaveheating, microwaves, which are electromagnetic waves, are emitted at the sample. Conventional heating starts by removing the moisture found at the surface of the sample using conduction, convection or radiation. To remove the moisture found in the sample, thermal conduction is conducted so that moisture is brought to the surface. This makes conventional heating a slow process and may require assistance with residual heat. The rate of conventional heating also depends on the sample that is being heated. The specific heat, thermal conductivity, density and viscosity of the material also control the rate at which conventional heating is completed. The physical characteristics of the material makes conventional heating non-uniform as certain edges and surfaces may get contact from the heat while other surfaces and edges may get less contact from the heat.

Microwave heating utilizes a bench scale oven for research purposes. The bench scales oven, such as a ETHOS-EZ that is $1.2 \mathrm{~kW}$, is a large scaled oven that can store various samples and can be set to the desired temperatures for the purpose of pretreatment (E Hosseini Koupaie, 2018). These samples can then be further analyzed.

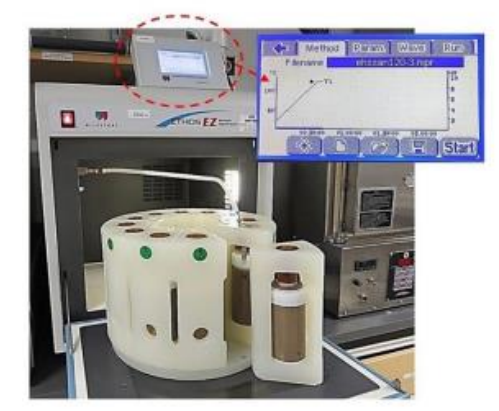

Figure 6: Microwave Heating System 
For research purpose, a general conventional heating system can utilize a pressure-sealed vessel (E Hosseini Koupaie, 2018). There are other components of a conventional heating system, which include thermocouple, safety valve, pressure gauge, external fiberglass insulator, DC power supply, digital multimeter, control software and a safety shield (E Hosseini Koupaie, 2018).

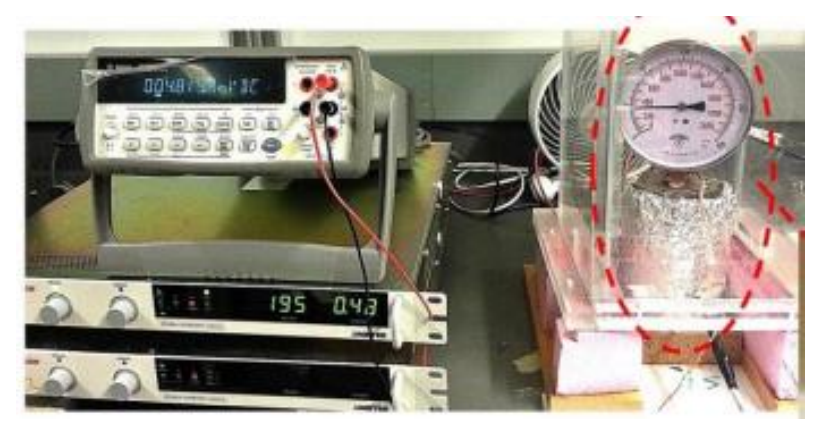

Figure 7: Conventional Heating System

Cambi is a commonly used process used outside in North America. It consists of three main components, the pulper, the reactor and the flash tank.

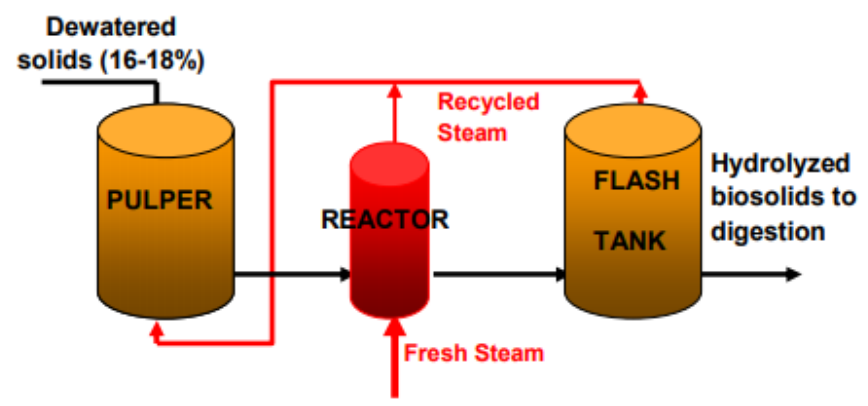

Figure 8: Cambi Process

The sludge must undergo pre-screening to remove material that can cause damage to the Cambi equipment (Mohammad Abu-Orf, 2012). Pretreatment is completed to dewater the sludge and then the sludge enters a tank for storage (Mohammad Abu-Orf, 2012). This tank will ensure flow into the pulper is equalized to accomplish a uniform flow rate (Mohammad Abu-Orf, 2012). 
Cambi operates as a batch reactor with standard volume of $12 \mathrm{~m}^{3}$ (Mohammad Abu-Orf, 2012). Therefore, each batch will be $7.6 \mathrm{~m}^{3}$ and will be flowed into the pulper (Mohammad Abu-Orf, 2012). The sludge entering the pulper is diluted using plant effluent to lower the concentration of total solids (Mohammad Abu-Orf, 2012). Once the sludge enters the pulper it is mixed, and recycled steam heats the mixture (Mohammad Abu-Orf, 2012). The preheated sludge then enters the reactor tank where the sludge will be heated using one ton of steam per one dry ton of sludge, to $165^{\circ} \mathrm{C}$, and a pressure between $120-130$ psi is applied (Mohammad Abu-Orf, 2012). The sludge, which has decreased total solids, then enters the flash tank (Mohammad Abu-Orf, 2012). The sludge from the flash tank must be treated to lower concentrations further and cool down (Mohammad Abu-Orf, 2012). It is then sent to final dewatering and can be sent out for its other uses (Mohammad Abu-Orf, 2012).

\subsubsection{Effect of Thermal Pretreatment on Volatile Fatty Acids Production}

In Table 4, volatile fatty acid concentrations are outlined for various kinds of thermal pretreatments. Reference 1 outlines microwave heating completed on combined primary sludge and waste activated sludge samples. The sludge samples were placed in a beaker and stored in a microwave oven (Aboulfoth \& El Gohary, 2014). The temperature was adjusted between 100 $200^{\circ} \mathrm{C}$ and at various times the samples were analyzed (Aboulfoth \& El Gohary, 2014). As seen

in Table 3, volatile fatty acid concentrations increase with time at set thermal pretreatment temperatures. For example, combined sludge, with a volatile fatty acid concentration of $2.00 \mathrm{~g} / \mathrm{L}$, is thermally pretreated in a microwave oven at $100^{\circ} \mathrm{C}$. The volatile fatty acid concentration increased slowly with time until ultimately at 240 minutes the volatile fatty acid concentration reached $6.30 \mathrm{~g} / \mathrm{L}$ (Aboulfoth \& El Gohary, 2014). Furthermore, volatile fatty acid concentration increased with increased temperature (Aboulfoth \& El Gohary, 2014). Combined sludge that was 
pretreated at $200^{\circ} \mathrm{C}$ resulted in higher concentrations of volatile fatty acids at each time increment compared to combined sludge that was pretreated at $100^{\circ} \mathrm{C}$ (Aboulfoth \& El Gohary, 2014). It was also concluded that microwave heating of combined sludge results in the manipulation of the structure of the sludge floc and would improve the solubility of the organic material found in sludge (Aboulfoth \& El Gohary, 2014).

Table 3: Detailed VFA Concentrations for Reference 1 (g/L)

\begin{tabular}{|c|c|c|c|c|c|}
\hline $\begin{array}{c}\text { Time } \\
(\mathbf{m i n})\end{array}$ & \multicolumn{5}{|c|}{ Thermal Pretreatment Temperature $\left({ }^{\circ} \mathrm{C}\right)$} \\
\hline & $\mathbf{1 0 0}$ & $\mathbf{1 2 5}$ & $\mathbf{1 5 0}$ & $\mathbf{1 7 5}$ & $\mathbf{2 0 0}$ \\
\hline $\mathbf{0}$ & 2.00 & 2.00 & 2.00 & 2.00 & 2.00 \\
\hline $\mathbf{3 0}$ & 2.40 & 2.55 & 2.70 & 2.85 & 2.90 \\
\hline $\mathbf{6 0}$ & 3.20 & 3.40 & 3.80 & 4.42 & 4.70 \\
\hline $\mathbf{1 2 0}$ & 4.55 & 4.60 & 5.00 & 6.40 & 6.20 \\
\hline $\mathbf{2 4 0}$ & 6.30 & 8.00 & 8.00 & 9.90 & 11.10 \\
\hline
\end{tabular}

Reference 2 also analyzes the effects of microwave heating, as a thermal pretreatment, on combined primary and waste activated sludge. The combined waste was collected from a wastewater treatment plant (E. Hosseini Koupaie, 2016). A 1200 W/ $2.45 \mathrm{GHz}$ bench scale microwave oven was used to complete microwave heating on the sludge sample (E. Hosseini Koupaie, 2016). The sample was placed inside the vessel where temperature and temperature rate was monitored (E. Hosseini Koupaie, 2016). Volatile fatty acid concentrations were determined during days 1, 3, 9, 25 and 59 of operation (E. Hosseini Koupaie, 2016). In Table 4, 
the initial and final concentrations of volatile fatty acids at various temperatures and temperature rates were outlined for the digestate.

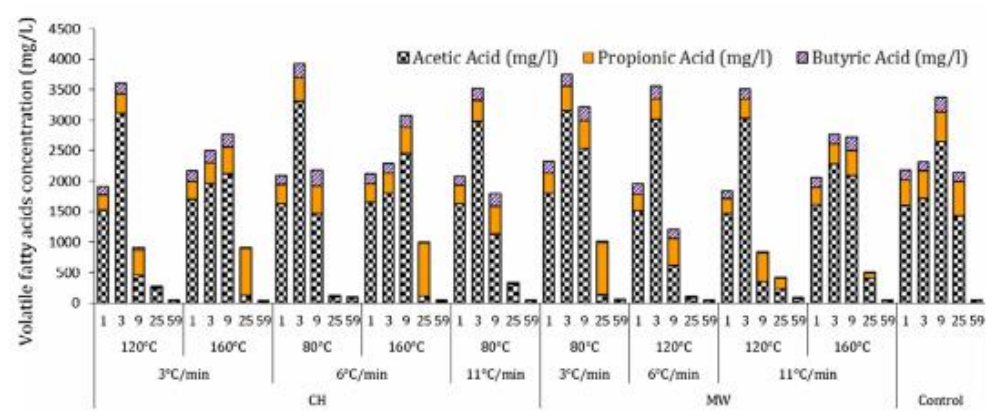

Figure 9: Volatile Fatty Acid Concentration for Ref 2 and 3

The initial volatile fatty acid concentration ranged between $1900-2300 \mathrm{mg} / \mathrm{L}$ and the final volatile fatty acid concentration, at 59 days, ranged between $100-150 \mathrm{mg} / \mathrm{L}$. As seen in Figure 11 , for microwave heating, the volatile fatty acid production trend is quite consistent with varying temperatures and temperature rate. The concentration increases to its maximum concentration on the third day and then decreases as the volatile fatty acids are utilized (E. Hosseini Koupaie, 2016). The volatile fatty acid concentrations were highest when temperatures were maintained at $80^{\circ} \mathrm{C}$ with a temperature ramp rate of $3^{\circ} \mathrm{C} / \mathrm{min}$ (E. Hosseini Koupaie, 2016). The maximum volatile fatty acid concentration for this case is approximately $3750 \mathrm{mg} / \mathrm{L}$ (E. Hosseini Koupaie, 2016).

Reference 3 analyzes the effects of conventional heating, completed as thermal pretreatment, on combined primary sludge and waste activated sludge. Once again, the combined sludge sample was retrieved from a wastewater treatment plant. For conventional heating, a custom-made conventional heating system was created. Like the previous scenario, the temperature and temperature ramp rate can be controlled (E. Hosseini Koupaie, 2016). The volatile fatty acid concentrations were determined at days 1, 3, 9, 25 and 53 days of operation (E. 
Hosseini Koupaie, 2016). In Table 4, the initial and final concentrations of volatile fatty acids at various temperatures and temperature rates were outlined for the digestate. The initial volatile fatty acid concentration ranged between $1900-2250 \mathrm{mg} / \mathrm{L}$ and the final volatile fatty acid concentration, at 59 days, ranged between $100-200 \mathrm{mg} / \mathrm{L}$ (E. Hosseini Koupaie, 2016). As seen in Figure 11, for convention heating, the volatile fatty acid production trend is consistent with varying temperatures and temperature rates (E. Hosseini Koupaie, 2016). The volatile fatty acid concentration increases to its maximum concentration on the third day and then decreases. The volatile fatty acid concentrations were at its highest at a temperature of $80^{\circ} \mathrm{C}$ with a temperature rate of $6^{\circ} \mathrm{C} / \mathrm{min}$ (E. Hosseini Koupaie, 2016). The maximum concentration of volatile fatty acids for this case is approximately $3800 \mathrm{mg} / \mathrm{L}$ (E. Hosseini Koupaie, 2016). It is concluded, for the second and third scenario, that the volatile fatty acids are utilized in the first 25 days (E. Hosseini Koupaie, 2016). Furthermore, in correlation to volatile fatty acid production, the maximum ultimate biogas yield, of $497.5 \mathrm{~mL} / \mathrm{g}$ VS added, for this sample of combined sludge was achieved from digestate that underwent thermal pretreatment at $80^{\circ} \mathrm{C}$ at a temperature ramp rate of $3^{\circ} \mathrm{C} / \mathrm{min}$ (E. Hosseini Koupaie, 2016). The volatile fatty acid concentrations were at its maximum under these conditions (E. Hosseini Koupaie, 2016). It was also observed that the minimum ultimate biogas yield, of $423.5 \mathrm{~mL} / \mathrm{g}$ VS added, for this sample of combined sludge was achieved from digestate that underwent thermal pretreatment at $160^{\circ} \mathrm{C}$ at a temperature ramp rate of $11^{\circ} \mathrm{C} / \mathrm{min}$. As observed in Figure 11, it is also evident that under these conditions the volatile fatty acid concentrations were at its lowest (E. Hosseini Koupaie, 2016). Therefore, higher temperatures at higher temperature ramp rates lead to lower concentrations of volatile fatty acids and low yields of biogas. 
Finally, Reference 4, from Table 4, outlines the effects of Cambi pretreatment completed on waste activated sludge on volatile fatty acid production. The waste activated sludge is retrieved from a wastewater treatment plant. It then was put through the Cambi process outlined above. After the thermal pretreatment, the waste activated sludge underwent anaerobic digestion. Anaerobic digestion produced digestate with a volatile fatty acid concentration of $15-25 \mathrm{~g} / \mathrm{L}$ ( $\mathrm{F}$. Morgan-Sagastume, 2011). Furthermore, it was concluded that the volatile fatty acid yield and production rate for waste activated sludge, that completed Cambi pretreatment, was much higher compared to raw waste activated sludge that was fed into the anaerobic digester (F. MorganSagastume, 2011). 
Table 4: Effects of Thermal Pretreatment on VFA Production

\begin{tabular}{|c|c|c|c|c|c|c|c|c|c|}
\hline $\begin{array}{c}\text { Ref } \\
\#\end{array}$ & $\begin{array}{c}\text { Type of } \\
\text { Thermal } \\
\text { Pretreatment }\end{array}$ & $\begin{array}{l}\text { Type of } \\
\text { Waste }\end{array}$ & $\begin{array}{c}\text { Temp } \\
\text { Ramp } \\
\text { Rate } \\
\left({ }^{\circ} \mathrm{C} /\right. \\
\text { min) }\end{array}$ & $\begin{array}{l}\text { Temp } \\
\left({ }^{\circ} \mathrm{C}\right)\end{array}$ & Time & $\begin{array}{l}\text { Fermenter } \\
\text { Condition }\end{array}$ & Initial VFA & $\begin{array}{c}\text { Final VFA } \\
\text { Concentratio } \\
\mathbf{n}\end{array}$ & Ref \\
\hline 1 & Microwave Heating & $\begin{array}{l}\text { Combined } \\
\text { Primary } \\
\text { Sludge and } \\
\text { Waste } \\
\text { Activated } \\
\text { Sludge }\end{array}$ & - & 200 & $240 \mathrm{~min}$ & - & $2.00 \mathrm{~g} / \mathrm{L}$ & $11.10 \mathrm{~g} / \mathrm{L}$ & $\begin{array}{c}\text { A.M. } \\
\text { Aboulfoth et } \\
\text { al (2014) }\end{array}$ \\
\hline \multirow[t]{3}{*}{2} & \multirow[t]{3}{*}{ Microwave Heating } & \multirow{3}{*}{$\begin{array}{l}\text { Combined } \\
\text { Primary } \\
\text { Sludge and } \\
\text { Waste } \\
\text { Activated } \\
\text { Sludge }\end{array}$} & 3 & 80 & 59 days & Thermophilic & $2300 \mathrm{mg} / \mathrm{L}$ & $150 \mathrm{mg} / \mathrm{L}$ & $\begin{array}{c}\text { E Hosseini } \\
\text { Koupaie et al } \\
\text { (2016) }\end{array}$ \\
\hline & & & 6 & 120 & 59 days & Thermophilic & $1900 \mathrm{mg} / \mathrm{L}$ & $100 \mathrm{mg} / \mathrm{L}$ & $\begin{array}{c}\text { E Hosseini } \\
\text { Koupaie et al } \\
(2016)\end{array}$ \\
\hline & & & 11 & 120,160 & 59 days & Thermophilic & $\begin{array}{c}\text { @ } 120-2000 \\
\mathrm{mg} / \mathrm{L} \\
\text { @ } 160-2000 \\
\mathrm{mg} / \mathrm{L}\end{array}$ & $\begin{array}{ll}@ & 120-150 \mathrm{mg} / \mathrm{L} \\
@ 160-100 \mathrm{mg} / \mathrm{L}\end{array}$ & $\begin{array}{c}\text { E Hosseini } \\
\text { Koupaie et al } \\
(2016)\end{array}$ \\
\hline \multirow[t]{3}{*}{3} & \multirow[t]{3}{*}{$\begin{array}{l}\text { Conventional } \\
\text { Heating }\end{array}$} & \multirow{3}{*}{$\begin{array}{c}\text { Combined } \\
\text { Primary } \\
\text { Sludge and } \\
\text { Waste } \\
\text { Activated } \\
\text { Sludge }\end{array}$} & 3 & 120,160 & 59 days & Thermophilic & $\begin{array}{c}\text { @ } 120-1900 \\
\mathrm{mg} / \mathrm{L} \\
\text { @ } 160-2250 \\
\mathrm{mg} / \mathrm{L}\end{array}$ & $\begin{array}{l}\text { @ } 120-100 \mathrm{mg} / \mathrm{L} \\
\text { @ } 160-190 \mathrm{mg} / \mathrm{L}\end{array}$ & $\begin{array}{c}\text { E Hosseini } \\
\text { Koupaie et al } \\
(2016)\end{array}$ \\
\hline & & & 6 & 80,160 & 59 days & Thermophilic & $\begin{array}{c}\text { @ } 80-2050 \mathrm{mg} / \mathrm{L} \\
@ 160-2000 \\
\mathrm{mg} / \mathrm{L} \\
\end{array}$ & $\begin{array}{l}@ 80-200 \mathrm{mg} / \mathrm{L} \\
@ 160-100 \mathrm{mg} / \mathrm{L}\end{array}$ & $\begin{array}{c}\text { E Hosseini } \\
\text { Koupaie et al } \\
(2016) \\
\end{array}$ \\
\hline & & & 11 & 80 & 59 days & Thermophilic & $2000 \mathrm{mg} / \mathrm{L}$ & $150 \mathrm{mg} / \mathrm{L}$ & $\begin{array}{c}\text { E Hosseini } \\
\text { Koupaie et al } \\
(2016) \\
\end{array}$ \\
\hline 4 & Cambi & $\begin{array}{c}\text { Waste } \\
\text { Activated } \\
\text { Sludge } \\
\end{array}$ & - & 42 & $1-6$ days & - & - & $15-20 \mathrm{~g} / \mathrm{L}$ & $\begin{array}{l}\text { F. Morgan- } \\
\text { Sagastume et } \\
\text { al (2011) }\end{array}$ \\
\hline
\end{tabular}




\subsection{Chemical Pretreatment}

The purpose of chemical pretreatment is to utilize strong acids, alkalis or oxidants to destroy organic compounds (Javkhlan Ariunbaatar, 2014). The effectiveness of chemical pretreatment depends on the method type, such as acidic, alkaline or ozone, and substrate type (Javkhlan Ariunbaatar, 2014). Anaerobic digestion is best performed on sludge that has a higher pH making it more basic (Javkhlan Ariunbaatar, 2014). Therefore, alkaline pretreatment is considered the most appropriate chemical pretreatment because alkaline dilutes the acidity of compounds (Javkhlan Ariunbaatar, 2014). Other pretreatments such as ozonation can also be applied on sludge to ensure adequate biogas production and hydrolysis of sludge (Javkhlan Ariunbaatar, 2014). Furthermore, substrates that are easily biodegradable and contain large amounts of carbohydrates are considered insufficient substrate for chemical pretreatment (Javkhlan Ariunbaatar, 2014). This is because it can cause an excessive amount of volatile fatty acid production, which will negatively affect the methanogenesis stage of anaerobic digestion (Javkhlan Ariunbaatar, 2014). Substrates that consist high amounts of lignin are considered optimal substrate for chemical pretreatment (Javkhlan Ariunbaatar, 2014).

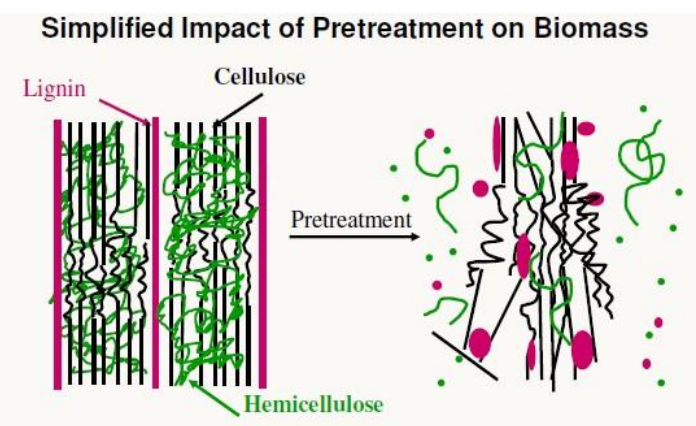

Figure 10: Effect of Chemical Pretreatment

\subsubsection{Types of Chemical Pretreatment}

Alkaline pretreatment utilizes alkaline reagents, such as sodium hydroxide, calcium hydroxide, potassium hydroxide, aqueous ammonia, and ammonia hydroxide (Javkhlan 
Ariunbaatar, 2014). Higher alkaline reagents are considered for chemical pretreatment, as substrates tend to consume the alkaline (Javkhlan Ariunbaatar, 2014). The first reactions that take place during alkaline pretreatment are solvation, which is when a solvent and a solute react to stabilize solute, and saphonication, which is when alkaline allows the conversion of fats and oils into alcohols (Javkhlan Ariunbaatar, 2014). During these reactions, solids swell, which cause the surface area to increase making it easier for anaerobic microbes to access the substrate (Javkhlan Ariunbaatar, 2014). Through other chemical reactions, that occur post solvation and saphonication, allow for increased COD solubilization (Javkhlan Ariunbaatar, 2014).

Furthermore, acids that are formed due to degradation of the substrate are also neutralized through the simultaneous reactions (Javkhlan Ariunbaatar, 2014). All in all, like all chemical pretreatment methods, the effectiveness of alkaline pretreatment depends on the physical and chemical structure of the substrate and the pretreatment conditions. Therefore, alkaline pretreatment is most effective on substrates that acquire a small amount of lignin such as hardwood, herbaceous crops and residual agricultural crops.

Acid pretreatment is most effective on lignocellulosic substrates because, unlike alkaline pretreatment, it is more successful at breaking down lignin content (Javkhlan Ariunbaatar, 2014). Acid pretreatment is also seen as effective because it can allow hydrolytic microbes to work productively in acidic conditions (Javkhlan Ariunbaatar, 2014). The driving reaction due to acid pretreatment is the hydrolysis of hemicellulose into monosaccharaides (Javkhlan Ariunbaatar, 2014). During this reaction, lignin condensates and precipitates (Javkhlan Ariunbaatar, 2014). Strong acid pretreatments are deemed as ineffective as strong acid reactions with the sludge allows to produce unwanted products, such as furfural and hydroxymethylfurfural (Javkhlan Ariunbaatar, 2014). To avoid this, acid treatment is conducted with the use of diluted acids and is 
completed along with thermal pretreatment to avoid utilizing a large amount of acids (Javkhlan Ariunbaatar, 2014). Acid pretreatment is also considered disadvantageous because the increased degradation of complex substrates causes the reduction in sugars for the fermentation stage of anaerobic digestion (Javkhlan Ariunbaatar, 2014). Furthermore, the process is considered costly as the acids used for the pretreatment are costly and the process of diluting the product of the sludge with acid before anaerobic digestion is costly (Javkhlan Ariunbaatar, 2014).

Ozone pretreatment has been gaining recognition as a form of chemical pretreatment. This is because, compared to other chemical pretreatment, ozone pretreatment does not leave behind salt and chemical residuals (Javkhlan Ariunbaatar, 2014). Also, ozone pretreatment also allows for the destruction of pathogens (Javkhlan Ariunbaatar, 2014). Ozone is a strong oxidant that reacts with organic matter directly and indirectly (Javkhlan Ariunbaatar, 2014). The structure of the reactant drives the direct reaction and the hydroxyl radicals drive the indirect reaction (Javkhlan Ariunbaatar, 2014). This assists with decomposition of the substrate by making the organic matter easily biodegradable and giving bacteria, from anaerobic digestion, more access to react appropriately (Javkhlan Ariunbaatar, 2014).

\subsubsection{Effect of Chemical Pretreatment on Volatile Fatty Acids Production}

The effects on volatile fatty acids after the application of various kinds of chemical pretreatments to substrates are outlined in Table 5. Reference 1 represents ozone pretreatment completed on yard waste before anaerobic digestion. The lawn grass that was used is a form of perennial grass collected from a landscaping company (Liang Yu, 2014). The lawn grass was dried and then ground into smaller particle sizes (Liang Yu, 2014). The lawn grass was then introduced to $5.3 \%$ ozone at a dose of $0.79 \mathrm{~g} \mathrm{O}_{3} / \mathrm{g}$ TS in a stainless-steel reactor (Liang $\mathrm{Yu}$, 2014). The reaction time between ozone and the lawn grass was 10 minutes. Reference 1 also 
completed alkaline pretreatment on yard waste before anaerobic digestion (Liang Yu, 2014). The lawn grass was the same of that of the previous scenario. Instead of being introduced to ozone, the lawn grass, after being dried and ground, was soaked in $28-30 \%$ ammonia hydroxide (Liang $\mathrm{Yu}, 2014$ ). It was soaked in ammonia hydroxide at $50^{\circ} \mathrm{C}$ for 24 hours (Liang Yu, 2014).

Furthermore, Reference 1 also completed both ozone and alkaline pretreatment on yard waste before anaerobic digestion. The lawn grass underwent ozone pretreatment for 10 minutes under the same conditions mentioned previously and then underwent alkaline pretreatment for 6 hours under the same conditions mentioned previously (Liang Yu, 2014).

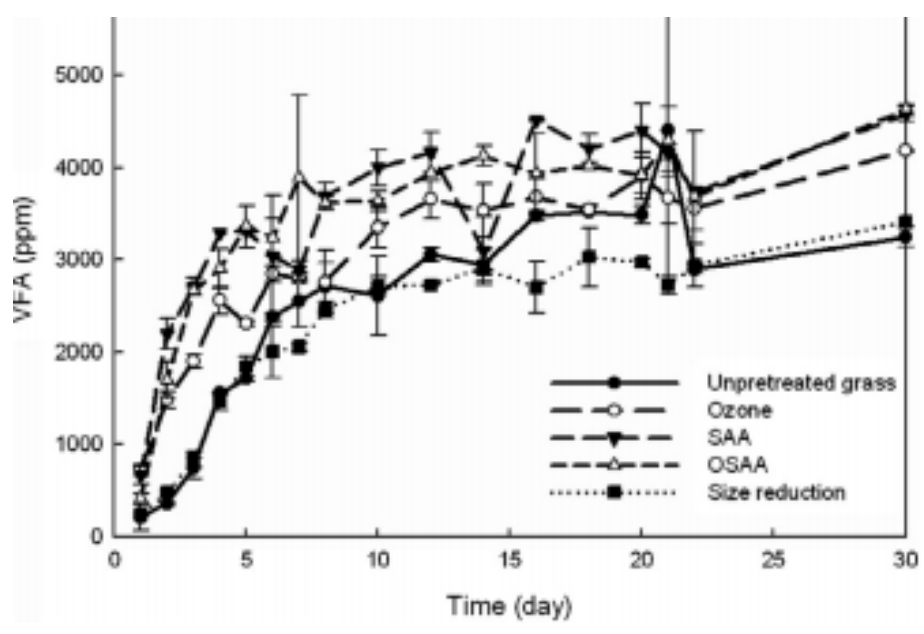

Figure 11: VFA Concentration after Ozone, Alkaline and Ozone with Alkaline Pretreatment

Samples of the digestate, that underwent the three different chemical pretreatments, were analyzed after 30 days of fermentation in the anaerobic digester (Liang Yu, 2014). In Figure 13, a large amount of the increase in volatile fatty acid concentration was completed in the first 7 days of fermentation (Liang Yu, 2014). After the seventh day the concentration of volatile fatty acid makes a smaller gradual increase in volatile fatty acid concentration (Liang Yu, 2014). The volatile fatty acid concentration of the ozone-pretreated substrate was $4000 \mathrm{ppm}$ at 30 days (Liang Yu, 2014). The volatile fatty acid concentration of the alkaline-pretreated substrate was 
$4500 \mathrm{ppm}$ at 30 days (Liang Yu, 2014). Similarly, the volatile fatty acid concentration of the ozone with alkaline pretreated substrate was 4500 ppm at 30 days (Liang Yu, 2014). Therefore, the lawn grass that underwent alkaline pretreatment achieved a higher concentration of volatile fatty acid (Liang Yu, 2014). Also, Figure 14 presents the effects on volatile fatty acid production for unpretreated lawn grass. Unpretreated lawn grass has a lower volatile fatty acid concentration, of approximately $3000 \mathrm{ppm}$, compared to the pretreated substrates (Liang Yu, 2014). Furthermore, the type of chemical pretreatment also affected biomethane production.

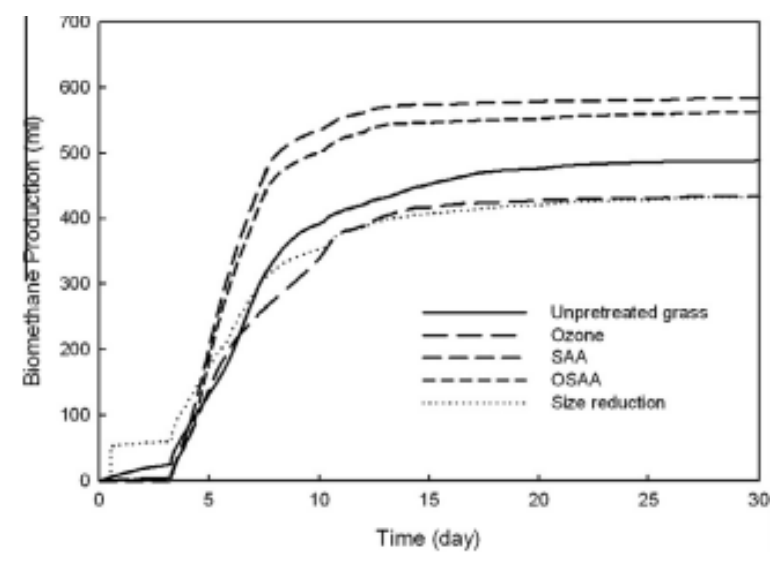

Figure 12: Biomethane Production

As shown in Figure 13, the biomethane production increased after alkaline pretreatment with a concentration of $481.0 \mathrm{~mL} \mathrm{CH}_{4} / \mathrm{g}$ VS whereas ozone pretreatment yielded lower production of biomethane (Liang Yu, 2014). The lawn grass that was pretreated with both ozone and alkaline had a lower biomethane production than the lawn grass pretreated only with alkaline pretreatment (Liang Yu, 2014). Ozone pretreatment has a large affect on the decrease in production of biomethane and volatile fatty acid. The production of biomethane runs in parallel with the production of volatile fatty acid (Liang Yu, 2014). Alkaline pretreated lawn grass presented higher yields of volatile fatty acid and biomethane (Liang Yu, 2014). Therefore, 
unpretreated lawn grass yield lower for volatile fatty acid production and biogas production compared to alkaline pretreated lawn grass.

Reference 2 completed both alkaline and acid pretreatment on food waste and presented its effect on volatile fatty acid production. The rice straw used was milled, sieved and stored in $45^{\circ} \mathrm{C}$ before being chemically pretreated (Gwon Woo Park, 2015). After drying, a 3.5g sample of rice straw was mixed with $57.5 \mathrm{~mL}$ of either sodium hydroxide or nitric acid at a reaction temperature of $150^{\circ} \mathrm{C}(\mathrm{Gwon}$ Woo Park, 2015). After alkaline pretreatment the solid composition of decreased from 61.90 to $40.75 \%$ (Gwon Woo Park, 2015). After acid pretreatment the solid composition decreased from 51.74 to $42.98 \%$ (Gwon Woo Park, 2015). With alkaline pretreatment there was a larger loss in lignin content whereas with acid pretreatment there was larger loss in hemicellulose as see in Figures 15 and 16.

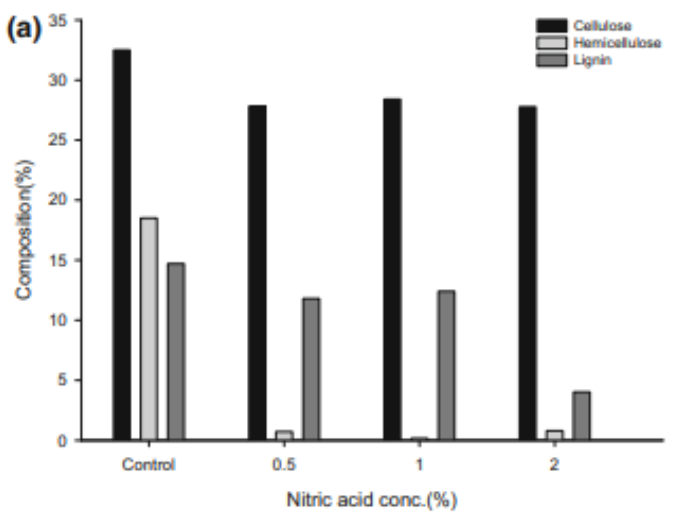

Figure 13: Solid Recovery After Acid Pretreatment

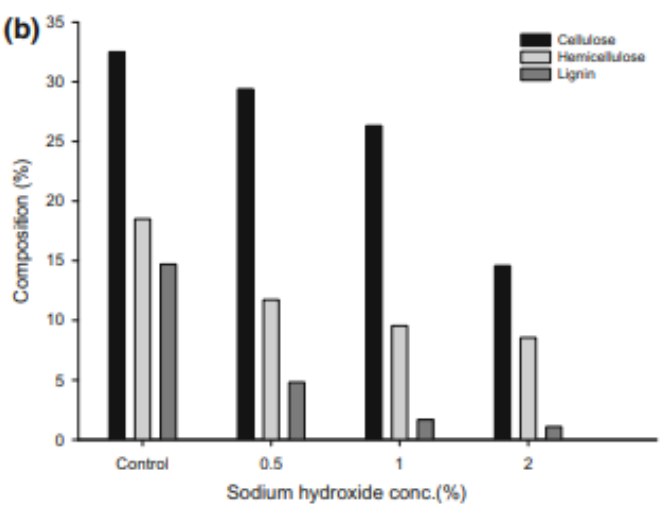

Figure 14: Solid Recovery After Alkaline Pretreatment

Also, seen in Figures 15 and 16 a higher concentration of sodium hydroxide and nitric acid resulted in a lower solid recovery. The volatile fatty acid concentrations after both alkaline and acid pretreatments are outlined in Table 5. For alkaline pretreatment, the highest concentration of $7.09 \mathrm{~g} / \mathrm{L}$ was achieved with 2\% sodium hydroxide (Gwon Woo Park, 2015). For acid 
pretreatment, the highest concentration of $6.00 \mathrm{~g} / \mathrm{L}$ was achieved with $0.5 \%$ nitric acid (Gwon Woo Park, 2015).

The volatile fatty acid production was proportional to the alkaline strength (Gwon Woo Park, 2015). This was not evident in nitric acid pretreatment because of inhibitors. This can be seen in Figures 17 and 18.
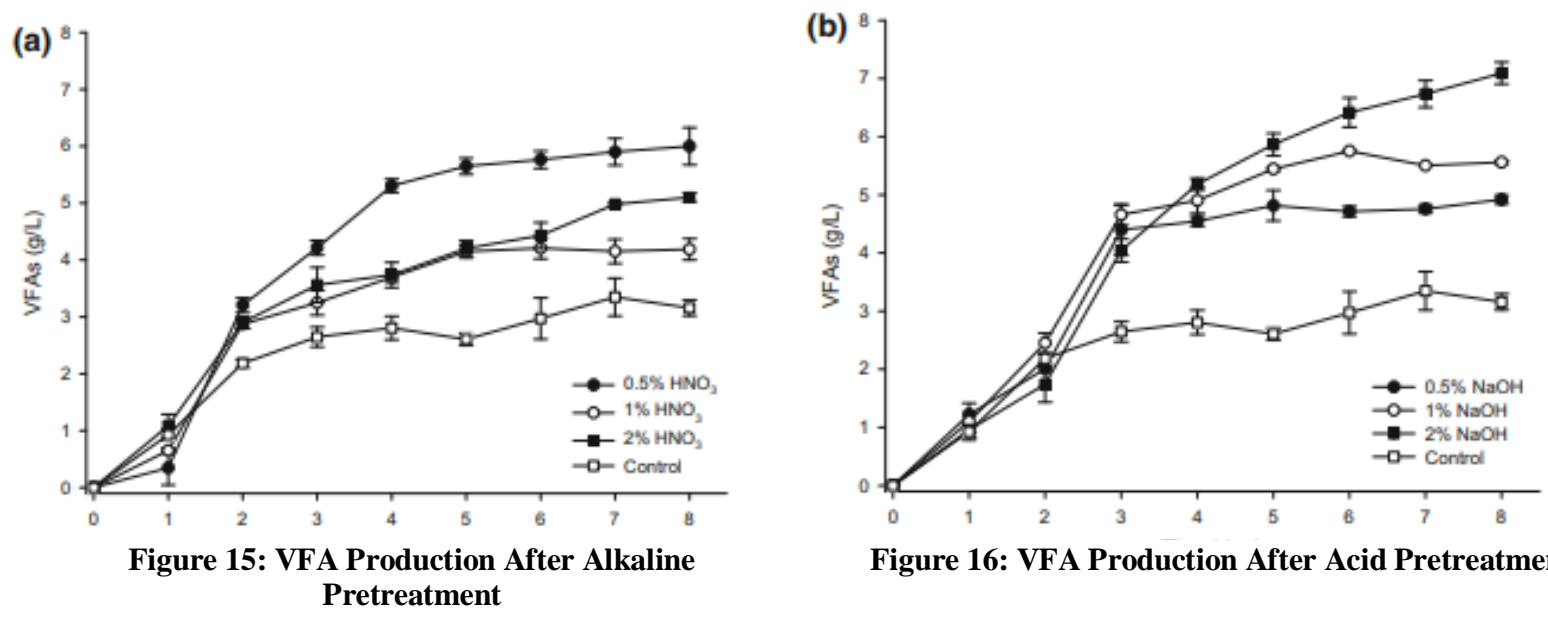

Figure 16: VFA Production After Acid Pretreatment

These inhibitors are furfural and hydroxymethylfurfural (Gwon Woo Park, 2015). When the concentration of furfural and hydroxymethylfurfural, during fermentation, are at its highest it will result in higher concentration of volatile fatty acid as it enhances the production of volatile fatty acid (Gwon Woo Park, 2015). These furfurals and hydroxymethylfurfural concentrations are highest using $0.5 \%$ nitric acid therefore causing a higher concentration of volatile fatty acids (Gwon Woo Park, 2015). All in all, alkaline pretreatment with 2\% sodium hydroxide resulted in a higher yield of volatile fatty acid. 
Table 5: Effects of Chemical Pretreatment on VFA Production

\begin{tabular}{|c|c|c|c|c|c|c|c|}
\hline $\begin{array}{c}\text { Ref } \\
\#\end{array}$ & $\begin{array}{c}\text { Type of } \\
\text { Chemical } \\
\text { Pretreatment }\end{array}$ & $\begin{array}{l}\text { Type of } \\
\text { Waste }\end{array}$ & $\begin{array}{c}\text { Reagent } \\
\text { Used }\end{array}$ & $\begin{array}{c}\text { Temperature } \\
\left({ }^{\circ} \mathrm{C}\right)\end{array}$ & $\begin{array}{c}\text { Reaction } \\
\text { Time }\end{array}$ & $\begin{array}{c}\text { VFA } \\
\text { Concentration }\end{array}$ & Reference \\
\hline \multirow[t]{3}{*}{1} & Ozone Pretreatment & Yard Waste & Ozone & - & $10 \mathrm{~min}$ & $\begin{array}{c}\text { @ } 30 \text { days }-4000 \\
\text { ppm }\end{array}$ & $\begin{array}{c}\text { L Yu et al } \\
(2018)\end{array}$ \\
\hline & $\begin{array}{c}\text { Alkaline } \\
\text { Pretreatment }\end{array}$ & Yard Waste & $\begin{array}{l}\text { Ammonia } \\
\text { Hydroxide }\end{array}$ & 50 & $24 \mathrm{~h}$ & $\begin{array}{c}\text { @ } 30 \text { days }-4500 \\
\text { ppm }\end{array}$ & $\begin{array}{c}\text { L Yu et al } \\
(2018)\end{array}$ \\
\hline & $\begin{array}{c}\text { Alkaline and Ozone } \\
\text { Pretreatment }\end{array}$ & Yard Waste & $\begin{array}{l}\text { Ammonia } \\
\text { Hydroxide }\end{array}$ & - & $\begin{array}{c}\text { Ozone }-10 \\
\text { min } \\
\text { Alkaline }-6 \\
\text { hr }\end{array}$ & $\begin{array}{c}\text { @ } 30 \text { days }-4500 \\
\text { ppm }\end{array}$ & $\begin{array}{c}\text { L Yu et al } \\
(2018)\end{array}$ \\
\hline \multirow[t]{8}{*}{2} & \multirow[t]{4}{*}{$\begin{array}{c}\text { Alkaline } \\
\text { Pretreatment }\end{array}$} & \multirow[t]{4}{*}{ Food Waste } & $\begin{array}{l}0 \% \text { Sodium } \\
\text { Hydroxide }\end{array}$ & 150 & $20 \mathrm{~min}$ & $3.35 \mathrm{~g} / \mathrm{L}$ & \multirow[t]{4}{*}{$\begin{array}{c}\text { G.W Park et al } \\
(2015)\end{array}$} \\
\hline & & & $\begin{array}{l}0.5 \% \text { Sodium } \\
\text { Hydroxide }\end{array}$ & 150 & $20 \mathrm{~min}$ & $4.81 \mathrm{~g} / \mathrm{L}$ & \\
\hline & & & $\begin{array}{l}1 \% \text { Sodium } \\
\text { Hydroxide }\end{array}$ & 150 & $20 \mathrm{~min}$ & $5.75 \mathrm{~g} / \mathrm{L}$ & \\
\hline & & & $\begin{array}{l}2 \% \text { Sodium } \\
\text { Hydroxide }\end{array}$ & 150 & $20 \mathrm{~min}$ & $7.09 \mathrm{~g} / \mathrm{L}$ & \\
\hline & \multirow[t]{4}{*}{ Acid Pretreatment } & \multirow[t]{4}{*}{ Food Waste } & $\begin{array}{c}0 \% \text { Nitiric } \\
\text { Acid }\end{array}$ & 150 & $20 \mathrm{~min}$ & $3.35 \mathrm{~g} / \mathrm{L}$ & \multirow[t]{4}{*}{$\begin{array}{c}\text { G.W Park et al } \\
(2015)\end{array}$} \\
\hline & & & $\begin{array}{c}0.5 \% \text { Nitiric } \\
\text { Acid }\end{array}$ & 150 & $20 \mathrm{~min}$ & $6.00 \mathrm{~g} / \mathrm{L}$ & \\
\hline & & & $\begin{array}{c}1 \% \text { Nitiric } \\
\text { Acid }\end{array}$ & 150 & $20 \mathrm{~min}$ & $4.21 \mathrm{~g} / \mathrm{L}$ & \\
\hline & & & $\begin{array}{c}2 \% \text { Nitiric } \\
\text { Acid }\end{array}$ & 150 & $20 \mathrm{~min}$ & $5.10 \mathrm{~g} / \mathrm{L}$ & \\
\hline
\end{tabular}




\subsection{Physical Pretreatment}

The purpose of physical pretreatment is to mechanically break down solid particles of the substrate (Javkhlan Ariunbaatar, 2014). This will allow for the cell compounds to be released, which in turn will increase the surface area (Javkhlan Ariunbaatar, 2014). An increased surface area will increase the efficiency of anaerobic digestion because the larger surface area will provide a larger contact area for anaerobic digestion bacteria (Javkhlan Ariunbaatar, 2014). It has been investigated and determined that a larger particle size allows for little degradation of COD and low methane production (Javkhlan Ariunbaatar, 2014). Physical pretreatment is beneficial because it is easy to implement and results in adequate dewatering of the final product from anaerobic digestion without the use of excessive energy (Javkhlan Ariunbaatar, 2014). The disadvantages of physical pretreatment are it does not assist in pathogen removal, which is one of the main objectives of anaerobic digestion (Javkhlan Ariunbaatar, 2014). Furthermore, the breaking down of solid particles in substrate can clog and damage the anaerobic digestion equipment (Javkhlan Ariunbaatar, 2014). Examples of physical pretreatments include sonication, lysis-centrifuge, liquid shear, and collision.

\subsubsection{Types of Physical Pretreatment}

Sonication applies ultrasound frequencies to the substrate (Ngoc Tuan Le, 2018). This allows for compression and rarefaction to occur in the substrate (Ngoc Tuan Le, 2018). Along with a large negative pressure, rarefaction can result in cavitation (Ngoc Tuan Le, 2018). When there was a low pressure, micro-bubbles were able to generate (Ngoc Tuan Le, 2018). These micro-bubbles slowly grow to a critical size where it begins to rapidly grow due to low pressure (Ngoc Tuan Le, 2018). The micro-bubble then collapses in the high-pressure period (Ngoc Tuan Le, 2018). The collapse results in small micro-bubbles, which will then undergo the same process (Ngoc Tuan Le, 2018). 


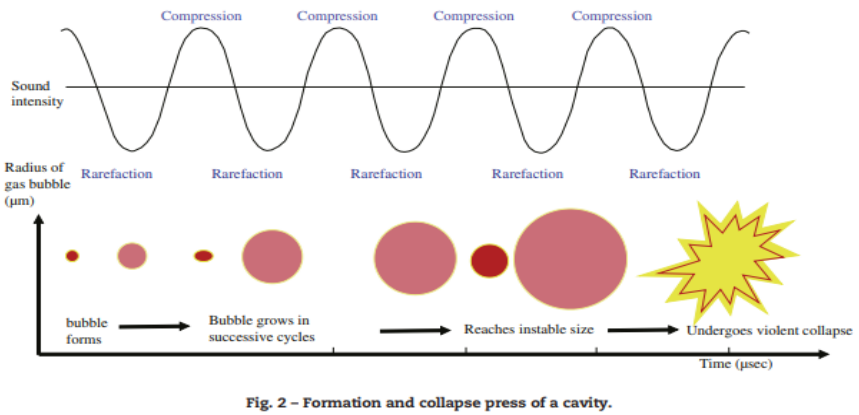

Figure 17: Sonication

Sonication is beneficial as it results in an easily biodegradable substrate, an increase in production of methane and an enhanced digestion time (Ngoc Tuan Le, 2018). It has been determined that sonication is an effective method of pretreatment for substrate coming from wastewater treatment plants and industrial plants (Ngoc Tuan Le, 2018).

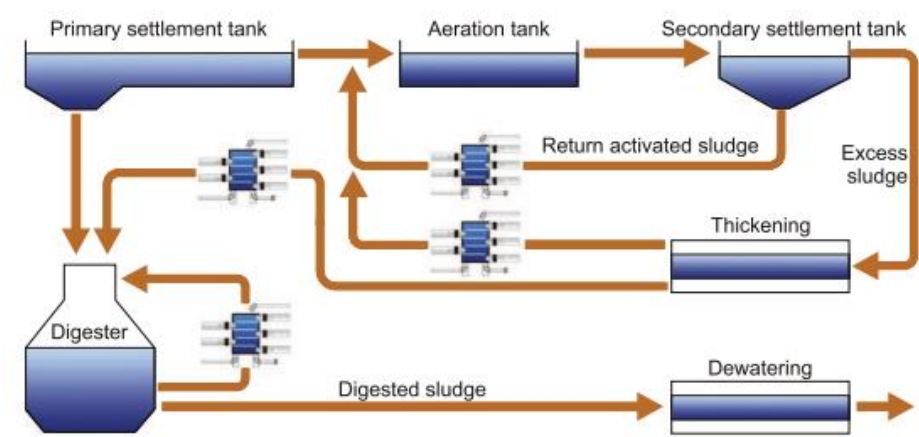

Figure 18: Sonication Mechanism Implementation in a Plant

It is not an effective method of pretreatment for lignocellulosic substrate (Ngoc Tuan Le, 2018). For sonication to be conducted on lignocellulosic substrate, sonication must be implemented with thermo-chemical pretreatment, such as thermo-NaOH treatment (Ngoc Tuan Le, 2018). This will ultimately improve the ability for lignocellulosic substrate to be digested and improve methane production (Ngoc Tuan Le, 2018). 


\subsubsection{Effect of Physical Pretreatment on Volatile Fatty Acids Production}

The effects on volatile fatty acids after the application of physical pretreatment to

substrates are outlined in Table 6 . Reference 1 represents sonication completed on food waste as physical pretreatment before anaerobic digestion. The food waste was collected from a school campus, processed and then stored at $4^{\circ} \mathrm{C}$ (Nuo Liu, 2018). Sonication pretreatment was then completed in an ultrasound reactor (Nuo Liu, 2018). The sonication pretreatment had two conditions that can be altered which are the ultrasonic time and ultrasonic densities (Nuo Liu, 2018). These conditions were altered to portray the effects on volatile fatty acid production due to change in ultrasonic densities and times (Nuo Liu, 2018). The food waste underwent sonication at three different ultrasonic densities (Nuo Liu, 2018). For each density, the food waste underwent sonication at four different ultrasonic times, 0, 5, 10, 15 minutes (Nuo Liu, 2018). The final concentration of volatile fatty acids after 120 hours in the fermenter is presented in Table 6. In Figures 21, 22 and 23 the production of volatile fatty acids over time in the fermenter is presented for the varying operation conditions of sonication.

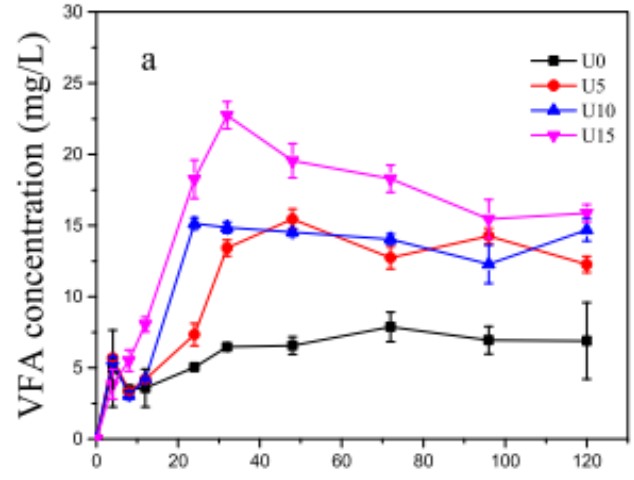

Figure 19: VFA Production with UD of $2 \mathrm{~W} / \mathrm{mL}$

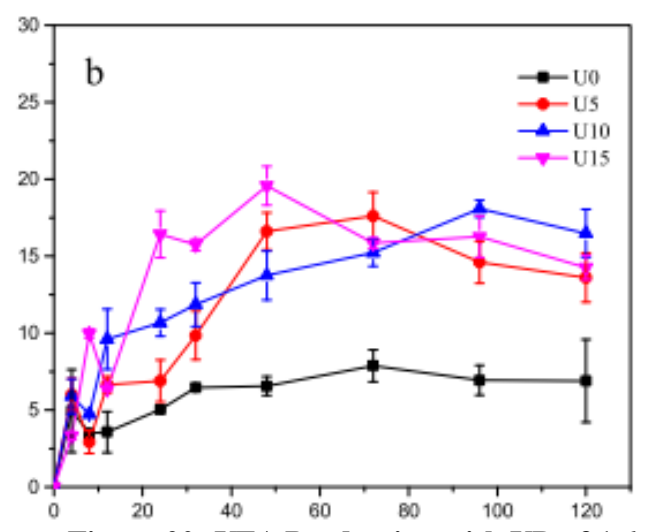

Figure 20: VFA Production with UD of 1.6 $\mathbf{W} / \mathbf{m L}$ 


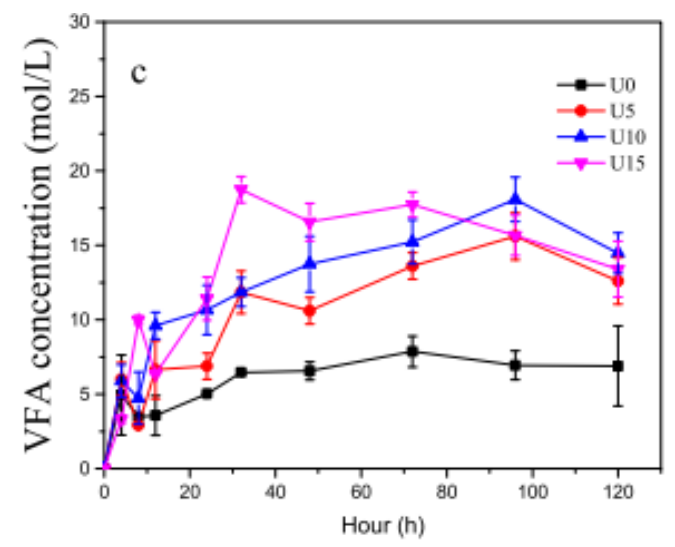

Figure 21: VFA Production with UD of $1.2 \mathrm{~W} / \mathrm{mL}$

The maximum volatile fatty acid concentration ranged between 7.87 to $22.7 \mathrm{~g} / \mathrm{L}$ and was achieved within 20 - 40 hours in fermentation (Nuo Liu, 2018). The maximum concentration of 22.7 $\mathrm{g} / \mathrm{L}$ was achieved with sonication completed at $2 \mathrm{~W} / \mathrm{mL}$ for 15 minutes (Nuo Liu, 2018). Furthermore, it was determined that higher concentrations of volatile fatty acids were achieved with a higher ultrasonic density of $2 \mathrm{~W} / \mathrm{mL}$ (Nuo Liu, 2018). As seen in Figures 21, 22 and 23, unsonicated food waste achieved their highest volatile fatty acid within $60-80$ hours in fermentation. This is due to the change in structure of the food waste particles. The cavitation completed due to sonication allows for the reduction of lag phase (Nuo Liu, 2018). Furthermore, volatile fatty acid production was high because sonication allowed for smaller food waste particles due to cavities formed in sonication and thermal effects from sonication (Nuo Liu, 2018). Smaller particles are ideal during hydrolysis and acidification allowing for a higher production of volatile fatty acids (Nuo Liu, 2018). All in all, sonication pretreatment done at higher ultrasonic times and densities assisted with achieving higher concentrations of volatile fatty acids due to the manipulation in the physical structure of the food waste particle. 
Table 6: Effects of Physical Pretreatment on VFA Production

\begin{tabular}{|c|c|c|c|c|c|c|}
\hline $\begin{array}{c}\text { Ref } \\
\#\end{array}$ & $\begin{array}{c}\text { Type of } \\
\text { Physical } \\
\text { Pretreatment }\end{array}$ & $\begin{array}{l}\text { Type of } \\
\text { Waste }\end{array}$ & Densities & Time & $\begin{array}{c}\text { VFA } \\
\text { Concentration }\end{array}$ & Ref \\
\hline \multirow[t]{12}{*}{1} & \multirow[t]{12}{*}{ Sonication } & \multirow[t]{12}{*}{ Food Waste } & \multirow[t]{4}{*}{$2 \mathrm{~W} / \mathrm{mL}$} & $0 \min$ & $5.1 \mathrm{mg} / \mathrm{L}$ & \multirow{12}{*}{$\begin{array}{l}\text { N Liu et al } \\
\text { (2018) }\end{array}$} \\
\hline & & & & $5 \mathrm{~min}$ & $13 \mathrm{mg} / \mathrm{L}$ & \\
\hline & & & & $10 \mathrm{~min}$ & $15.5 \mathrm{mg} / \mathrm{L}$ & \\
\hline & & & & $15 \min$ & $16.5 \mathrm{mg} / \mathrm{L}$ & \\
\hline & & & \multirow[t]{4}{*}{$1.6 \mathrm{~W} / \mathrm{mL}$} & $0 \mathrm{~min}$ & $5.1 \mathrm{mg} / \mathrm{L}$ & \\
\hline & & & & $5 \min$ & $12.5 \mathrm{mg} / \mathrm{L}$ & \\
\hline & & & & $10 \mathrm{~min}$ & $16 \mathrm{mg} / \mathrm{L}$ & \\
\hline & & & & $15 \mathrm{~min}$ & $14.5 \mathrm{mg} / \mathrm{L}$ & \\
\hline & & & \multirow[t]{4}{*}{$1.2 \mathrm{~W} / \mathrm{mL}$} & $0 \mathrm{~min}$ & $7 \mathrm{mg} / \mathrm{L}$ & \\
\hline & & & & $5 \mathrm{~min}$ & $12.5 \mathrm{mg} / \mathrm{L}$ & \\
\hline & & & & $10 \mathrm{~min}$ & $14 \mathrm{mg} / \mathrm{L}$ & \\
\hline & & & & $15 \mathrm{~min}$ & $13 \mathrm{mg} / \mathrm{L}$ & \\
\hline
\end{tabular}

\subsection{Combined Pretreatment}

As discussed previously, combined pretreatments are implemented on substrates so that the pretreatment can reach maximum effectiveness. One pretreatment method achieves that the other pretreatment cannot. Combined pretreatment leads to improvement in biogas production and the kinetic processes of anaerobic digestion. There are two types of combined pretreatment and those include thermo-chemical pretreatment and thermo-physical pretreatment.

\subsubsection{Effect of Combined Pretreatment on Volatile Fatty Acids Production}

The effects on volatile fatty acids after the application of combined pretreatment to substrates are outlined in Table 7 . Reference 1 represents thermochemical pretreatment completed on waste activated sludge and its affect on volatile fatty acid production. It analyzes the effects of different kinds of alkaline reagents used for chemical pretreatment before waste activated sludge is fed into the anaerobic digestion process (Aijuan Zhou, 2013). The waste activated sludge was collected from a wastewater treatment plant (Aijuan Zhou, 2013).

Dewatering was completed to the sludge and then the sludge characteristics were altered so that 
the total suspended solids were $70 \mathrm{~g} / \mathrm{L}$ by soaking the waste in water at $95^{\circ} \mathrm{C}$ (Aijuan Zhou, 2013). Reference 2 begins by completing chemical pretreatment with sodium hydroxide as the driving reagent. The waste activated sludge is fed into the pretreatment tank where sodium hydroxide with a concentration of $5.0 \mathrm{~mol} / \mathrm{L}$ is also fed (Lei Yu, 2018). The mixture of the sodium hydroxide with the waste activated sludge adjusted the $\mathrm{pH}$ to 12 (Lei Yu, 2018). The sludge then underwent thermal pretreatment where it was heated at $70^{\circ} \mathrm{C}$ for 2 hours (Lei Yu, 2018). The second experiment Reference 2 completed was rather using sodium hydroxide, chemical pretreatment was completed with mixed alkaline (Lei Yu, 2018). The mixed alkaline include calcium hydroxide with a concentration of $4.0 \mathrm{~mol} / \mathrm{L}$ and sodium hydroxide with a concentration of $1.0 \mathrm{~mol} / \mathrm{L}$ (Lei Yu, 2018). Again, thermal pretreatment is completed to the waste once a $\mathrm{pH}$ of 12 was reached at $70^{\circ} \mathrm{C}$ for 2 hours (Lei Yu, 2018). The third experiment Reference 2 completed utilized calcium dioxide for chemical pretreatment (Lei Yu, 2018). The concentration of the calcium dioxide is $4.0 \mathrm{~mol} / \mathrm{L}$ (Lei Yu, 2018). Again; thermal pretreatment is completed on the waste at $70^{\circ} \mathrm{C}$ for 2 hours (Lei $\mathrm{Yu}, 2018$ ). The concentration of volatile fatty acids after thermo-sodium hydroxide pretreatment and fermentation was $7.48 \pm 0.64 \mathrm{~g} / \mathrm{L}$ (Lei $\mathrm{Yu}, 2018)$. The concentration of volatile fatty acids after thermo-mixed alkaline pretreatment and fermentation was $6.93 \pm 0.63 \mathrm{~g} / \mathrm{L}$ (Lei Yu, 2018). The concentration of volatile fatty acids after thermo-calcium dioxide pretreatment and fermentation was $7.91 \pm 0.64 \mathrm{~g} / \mathrm{L}$ (Lei Yu, 2018). Organic matter and carbohydrates are driving components for volatile fatty acid production (Lei $\mathrm{Yu}, 2018)$. After fermentation, the organic matter present was much higher in digestate that was pretreated with thermo-sodium hydroxide compared to digestate pretreated with thermo-calcium dioxide. Nonetheless, the concentration of volatile fatty acid remained similar (Lei Yu, 2018). It was also determined that the type of microbial present in sludge can affect the production of 
volatile fatty acids (Lei Yu, 2018). Chemicals, such as the reagents used for chemical pretreatment, can affect the microbial community of the sludge (Lei Yu, 2018). This explains why the volatile fatty acid concentration was higher in digestate that was pretreated with thermocalcium dioxide rather than digestate that was pretreated with thermo-mixed alkaline (Lei Yu, 2018). Furthermore, it was determined another reason for the high concentration after pretreatment with thermo- calcium dioxide is because calcium dioxide has a slow decomposition rate which allows for the creation of calcium hydroxide and hydrogen peroxide (Lei Yu, 2018). Calcium hydroxide and hydrogen peroxide allow enhances hydrolysis, which affects the production of volatile fatty acids (Lei Yu, 2018). The concentration of soluble chemical oxygen demand can also affect the production of volatile fatty acid (Lei Yu, 2018). The soluble chemical oxygen demand was higher in digestate that was pretreated with thermo-calcium dioxide therefore allowing for a higher production of volatile fatty acid (Lei Yu, 2018). The composition of the volatile fatty acid consisted of acetate, propionate and butyrate with acetate being the dominant component (Lei Yu, 2018). These three volatile fatty acids comprised of 79.74\% after thermo-sodium hydroxide, $85.70 \%$ after thermo-mixed alkaline and $90.31 \%$ after thermocalcium dioxide (Lei Yu, 2018). In the digestate that underwent thermo-calcium dioxide pretreatment acetate made up $60.81 \%$ (Lei Yu, 2018). All in all, the study determined that organic matter concentration does not have much affect on the volatile fatty acid production; microbial present due to sludge and chemical reaction can affect the volatile fatty acid production, the chemical characteristics of the reagent used for chemical pretreatment has an affect on volatile fatty acid production and finally the soluble chemical oxygen demand concentration has an affect on volatile fatty acid production. 
Table 7: Effects of Combined Pretreatment on VFA Production

\begin{tabular}{|c|c|c|c|c|c|c|c|c|}
\hline $\begin{array}{c}\text { Ref } \\
\#\end{array}$ & $\begin{array}{l}\text { Type of Combined } \\
\text { Pretreatment }\end{array}$ & $\begin{array}{l}\text { Type of } \\
\text { Waste }\end{array}$ & $\begin{array}{l}\text { Reagent } \\
\text { Used }\end{array}$ & pH & $\begin{array}{c}\text { Temperature } \\
\left({ }^{\circ} \mathrm{C}\right)\end{array}$ & $\begin{array}{c}\text { Reaction } \\
\text { Time }\end{array}$ & $\begin{array}{c}\text { VFA } \\
\text { Concentration }\end{array}$ & Ref \\
\hline 1 & $\begin{array}{l}\text { Thermochemical } \\
\text { Pretreatment }\end{array}$ & $\begin{array}{c}\text { Waste } \\
\text { Activated } \\
\text { Sludge }\end{array}$ & Alkaline & - & 81 & $20 \mathrm{~min}$ & $5118 \mathrm{mg} / \mathrm{L}$ & $\begin{array}{l}\text { A Zhou et al } \\
\text { (2013) }\end{array}$ \\
\hline \multirow[t]{3}{*}{2} & $\begin{array}{c}\text { Thermochemical } \\
\text { Pretreatment }\end{array}$ & $\begin{array}{c}\text { Waste } \\
\text { Activated } \\
\text { Sludge }\end{array}$ & $\begin{array}{c}\text { Sodium } \\
\text { Hydroxide }\end{array}$ & 12 & 70 & $2 \mathrm{hr}$ & $7.48 \pm 0.64 \mathrm{~g} / \mathrm{L}$ & \multirow[t]{3}{*}{$\begin{array}{c}\text { L Yu et al } \\
(2018)\end{array}$} \\
\hline & $\begin{array}{l}\text { Thermochemical } \\
\text { Pretreatment }\end{array}$ & $\begin{array}{c}\text { Waste } \\
\text { Activated } \\
\text { Sludge }\end{array}$ & $\begin{array}{l}\text { Calcium } \\
\text { Hydroxide } \\
\text { and } \\
\text { Sodium } \\
\text { Hydroxide }\end{array}$ & 12 & 70 & $2 \mathrm{hr}$ & $6.93 \pm 0.63 \mathrm{~g} / \mathrm{L}$ & \\
\hline & $\begin{array}{c}\text { Thermochemical } \\
\text { Pretreatment }\end{array}$ & $\begin{array}{c}\text { Waste } \\
\text { Activated } \\
\text { Sludge }\end{array}$ & $\begin{array}{c}\text { Calcium } \\
\text { Hydroxide }\end{array}$ & 12 & 70 & $2 \mathrm{hr}$ & $7.91 \pm 0.64 \mathrm{~g} / \mathrm{L}$ & \\
\hline
\end{tabular}




\subsection{Conclusion}

Volatile fatty acids are short chain acids that are formed after the acidogenesis stage of anaerobic digestion (Wee Shen Lee, 2013). Substrates that have a high concentration in organics, such as sludge, food waste and yard waste, have high concentrations of glucose and sucrose (Wee Shen Lee, 2013). The proteins and lipids in the substrate hydrolyze and convert into monosaccharides, amino acids and long chain fatty acids (Wee Shen Lee, 2013). Then, these monomers complete acidogenesis to be broken down into volatile fatty acids (Wee Shen Lee, 2013).

In conclusion, substrate type and pretreatment type have a major affect on the production of volatile fatty acids. The substrate types that are analyzed through this report are solid wastes, such as food waste and yards waste, and sludge, such as primary, waste activated, and combined sludge. The maximum concentrations and yields for volatile fatty acids were determined through various experiments and are outlined in Tables 1 and 2 . The pretreatment types that are analyzed through this report are thermal pretreatment, such as microwave, conventional heating and cambi, chemical pretreatment, such as alkaline, acid and ozone pretreatment, physical pretreatment, such as sonication, and finally thermochemical pretreatment. The maximum concentrations of volatile fatty acids are outlined in Tables 4, 5, 6, and 7. 


\section{References}

Aboulfoth, A., \& El Gohary, E. H. (2014). EFFECT OF THERMAL PRETREATMENT ON THE SOLUBILIZATION OF ORGANIC MATTERS IN A MIXTURE OF PRIMARY AND WASTE ACTIVATED SLUDGE . Journal of Urban and Environmental.

Aijuan Zhou, J. D. (2013). VFAs bioproduction from waste activated sludge by coupling pretreatments with Agaricus bisporus substrates conditioning. Process Biochemistry.

Britannica. (2019). Retrieved from Wastewater Treatment:

https://www.britannica.com/technology/wastewater-treatment

Cai Mengmeng, C. H. (2009). Optimal production of polyhydroxyalkanoates (PHA) in activated sludge fed by volatile fatty acids (VFAs) generated from alkaline excess sludge fermentation. Bioresource Technology.

Cigdem Eskicioglu, A. P. (2008). Synergetic pretreatment of sewage sludge by microwave irradiation in presence of $\mathrm{H} 2 \mathrm{O} 2$ for enhanced anaerobic digestion. Water Research.

E Hosseini Koupaie, T. J. (2018). Comparison of Different Electricity-Based Thermal Pretreatment Methods for Enhanced Bioenergy Production from Municipal Sludge. MDPI.

E. Hosseini Koupaie, C. E. (2016). Conventional heating vs. microwave sludge pretreatment comparison under identical heating/cooling profiles for thermophilic advanced anaerobic digestion. Waste Management.

Encyclopedia.com. (2019). Retrieved from Yard Waste: https://www.encyclopedia.com/environment/encyclopedias-almanacs-transcripts-andmaps/yard-waste

F. Morgan-Sagastume, S. P. (2011). Production of volatile fatty acids by fermentation of waste activated sludge pre-treated in full-scale thermal hydrolysis plants. Bioresource Technology.

Gwon Woo Park, I. K.-I.-C. (2015). Enhancement of volatile fatty acids production from rice straw. Bioprocesses Biosystem Eng.

Hafez, H. (2019). Lecture 3. Toronto.

Haiyan Wu, D. Y. (2009). The effect of $\mathrm{pH}$ on anaerobic fermentation of primary sludge at room temperature. Bioresource Technology. 
I. Maharaj, P. E. (2001). The role of HRT and low temperature on the acid-phase anaerobic. Elsevier.

Javkhlan Ariunbaatar, A. P. (2014). Pretreatment methods to enhance anaerobic digestion of organic solid. Applied Energy.

Kun Wang, J. Y. (2014). Anaerobic digestion of food waste for volatile fatty acids (VFAs) production with different types of inoculum: Effect of $\mathrm{pH}$. Bioresource Technology.

Lei Yu, W. Z. (2018). Evaluation of volatile fatty acids production and dewaterability of waste activated sludge with different thermo-chemical pretreatments. International Biodeterioation \& Biodegradation.

Lenntech. (2019). Retrieved from Water Treatment Solutions: https://www.lenntech.com/library/sludge/sorts/sludgesorts.htm

Liang Yu, M. B. (2014). Enhancing volatile fatty acid (VFA) and bio-methane production from lawn grass with pretreatment. Bioresource Technology, https://ac-els-cdncom.ezproxy.lib.ryerson.ca/S0960852414003940/1-s2.0-S0960852414003940main.pdf?_tid=73ef351a-fdb8-4805-b12bde1086c69915\&acdnat=1536505644_630223787fbce7bdf3ea3b472707bd0e.

Mohammad Abu-Orf, T. G. (2012). COMPARING THERMAL HYDROLYSIS PROCESSES (CAMBITM AND EXELYS ${ }^{\mathrm{TM}}$ ) FOR SOLIDS PRETREATMET PRIOR TO ANAEROBIC DIGESTION . Residuals and Biosolids.

NESC. (2003). Pipeline. Explaining the Activated Sludge Process, 2-3.

Ngoc Tuan Le, C. J.-L. (2018). An executive review of sludge pretreatment by sonication. HAL archives-ouvertes.

Nuo Liu, J. J. (2018). Enhancement of volatile fatty acid production and biogas yield from food waste following sonication pretreatment. Journal of Environmental Management.

Peng Zhang, Y. C. (2009). Waste activated sludge hydrolysis and short-chain fatty acids accumulation under mesophilic and thermophilic conditions: Effect of $\mathrm{pH}$. Water Research.

Su Jiang, Y. C. (2007). Effect of sodium dodecyl sulfate on waste activated sludge hydrolysis and acidification. Chemical Engineering Journal.

The International Water Association Publishing. (2019). Retrieved from Activated Sludge Process: https://www.iwapublishing.com/news/activated-sludge-process 
Wee Shen Lee, A. S. (2013). A review of the production and applications of waste-derived volatile. Chemical Engineering Journal, 2.

Wikipedia. (2013, March 31). Retrieved from Sewage Treatment:

https://en.wikipedia.org/wiki/Sewage_treatment

Wikipedia. (2019). Retrieved from Food Waste:

https://en.wikipedia.org/wiki/Food_waste\#United_States

Zhouying Ji, G. C. (2010). Effects of waste activated sludge and surfactant addition on primary sludge hydrolysis and short-chain fatty acids accumulation. Bioresource Technology. 